\title{
NEW INSIGHTS INTO POTENTIAL FUNCTIONS FOR THE PROTEIN 4.1 SUPERFAMILY OF PROTEINS IN KIDNEY EPITHELIUM
}

\author{
Venice Calinisan ${ }^{1}$, Dana Gravem ${ }^{1}$, Ray Ping-Hsu Chen ${ }^{1}$, Sachi Brittin ${ }^{1}$, Narla Mohandas ${ }^{2}$, Marie-Christine Lecomte ${ }^{3}$ \\ and Philippe Gascard ${ }^{1}$
}

${ }^{1}$ Department of Genome Biology, Life Sciences Division, Lawrence Berkeley National Laboratory, Berkeley, California $94720,{ }^{2}$ Red Cell Physiology Group, New York Blood Center, New York, New York 10021, ${ }^{3}$ INSERM U665, Institut National de Transfusion Sanguine, 75015 Paris, France

\section{TABLE OF CONTENTS}

1. Abstract

2. Introduction

3. Protein 4.1 structure

4. Cytoskeleton and kidney architecture and function

4.1. Renal 4.1 proteins

4.2. Renal ezrin

4.3. Renal ankyrins

5. Potential functions for renal 4.1 proteins

5.1. Methodology

5.2. Identification of binding partners for renal 4.1 proteins

5.3. Beta-Amyloid Precursor Protein: a key element in progression of neuropathies and potentially epitheliopathies

5.4. Cell signaling: importance of 14-3-3 proteins

5.5. Regulation of cell volume in response to osmotic stress: role of the swelling-activated chloride channel pICln

5.5.1. Mechanisms of regulation of cell volume

5.5.2. Properties of the cell swelling-activated chloride channel pICln

5.5.2.1. pICln: a versatile protein

5.5.2.2. Characterization of pICln/4.1 interaction

6. Protein 4.1 and ezrin: key players in control of cell proliferation

7. Conclusion

8. Acknowledgements

9. References

\section{ABSTRACT}

Members of the protein 4.1 family of adapter proteins are expressed in a broad panel of tissues including various epithelia where they likely play an important role in maintenance of cell architecture and polarity and in control of cell proliferation. We have recently characterized the structure and distribution of three members of the protein 4.1 family, 4.1B, 4.1R and $4.1 \mathrm{~N}$, in mouse kidney. We describe here binding partners for renal 4.1 proteins, identified through the screening of a rat kidney yeast two-hybrid system cDNA library. The identification of putative protein 4.1-based complexes enables us to envision potential functions for 4.1 proteins in kidney: organization of signaling complexes, response to osmotic stress, protein trafficking, and control of cell proliferation. We discuss the relevance of these protein 4.1-based interactions in kidney physio-pathology in the context of their previously identified functions in other cells and tissues. Specifically, we will focus on renal 4.1 protein interactions with beta amyloid precursor protein (beta-APP), 14-3-3 proteins, and the cell swelling-activated chloride channel pICln. We also discuss the functional relevance of another member of the protein 4.1 superfamily, ezrin, in kidney physiopathology.

\section{INTRODUCTION}

The cytoskeleton is composed of a complex network of proteins that participates in maintenance of cell architecture and polarity through proper sorting and retention of transmembrane proteins. Thus, cytoskeletal proteins 4.1 and ezrin act as scaffold proteins by bridging an increasing list of transmembrane proteins to actin filaments and specialized adapter and signaling molecules (1-9). These cytoskeleton-based interactions are dynamic and subject to regulation depending on cell activation and cell environment. The key role of protein 4.1 in membrane architecture and function is illustrated by the observation that a dramatic decrease or loss in protein 4.1 expression results in a concomitant decrease in the level of expression and mislocalization of transmembrane and membrane-associated proteins that normally interact with protein 4.1 (10-27). Members of the protein 4.1 superfamily have been originally thought to play exclusively a structural role. There is now strong evidence for their involvement in other cellular functions, including cell polarity $(3,15,28-31)$, nuclear architecture and cell division (32-45), control of cell volume in response to osmotic stress (46), and control of cell proliferation (47-53). As detailed later in this review, the complex gene organization of the four members of the protein 4.1 family likely plays a major role in tissue and cellular specialization of 4.1 proteins. 
In this review, we present evidence for potential interactions of the three major kidney protein 4.1 gene products with selected binding partners in an attempt to delineate the functions that these cytoskeletal proteins may play in kidney and in other epithelia. The potential functional relevance of protein 4.1 interactions with beta amyloid precursor protein (beta-APP), members of the 14-3-3 family of proteins, and the cell-swelling activated chloride channel pICln, will be explored. The involvement of another member of the protein 4.1 superfamily, ezrin, in kidney structure, function and pathology is also discussed in detail. Renal ankyrins will be evoked briefly since they are described in another chapter of this issue (see Mohler and Bennett).

\section{PROTEIN 4.1 STRUCTURE}

Protein 4.1 belongs to the Ezrin/Radixin/Moesin (ERM) superfamily of adapter proteins that bridge membrane proteins and actin filaments $(4,54)$. Members of the ERM family share a homologous region, referred to as the FERM (Four.1/Ezrin/Radixin/Moesin) domain (55), suggesting that they may associate with identical or related membrane proteins. The family of 4.1 proteins is composed of prototypical red blood cell 4.1R (56-59), and three homologs, 4.1G (60, 61), 4.1N (62-65) and 4.1B (66-69). Protein 4.1 genes differ in their expression pattern: 4.1R is predominantly expressed in hematopoietic tissues, and in regions of brain and kidney $(66,70,71) ; 4.1 \mathrm{G}$ shows a broad distribution $(60,61,70)$ but, unlike the three other 4.1 proteins, it is not expressed in kidney $(71,72) ; 4.1 \mathrm{~N}$ is mostly neuron- and kidney- specific with low expression in the retina and gastro-intestinal epithelium $(62,71)$; and $4.1 \mathrm{~B}$ is present in regions of brain, thymus, liver, gastro-intestinal tract, pancreas, kidney, and testis $(53,66,71-75)$. The four protein 4.1 genes have been mapped on both man and mouse chromosomes $(66,69)$. They share a similar organization characterized by the existence of multiple initiation sites combined with a large number of alternative exons. This results in the generation of a broad repertoire of isoforms from each protein 4.1 gene $(30,34,58,59,71$, 76-93).

Well-defined structural domains have been delineated within the protein 4.1 coding region (Figure 1) (94). As illustrated in Figure 2, the $30 \mathrm{kD}$ FERM domain, also referred to as MBD domain, mediates interaction of 4.1R and/or its homologs with numerous binding partners including various transmembrane proteins such as the anion exchanger AE1 (or band 3) (95-97), glycophorin C (25, 98-105), CD44 (23), nectin (106) and Neurexins such as Paranodin (107-110), PDZ domaincontaining proteins p55 $(12,19,111)$, discs large $(\mathrm{Dlg})$ protein, also referred to as synapse-associated protein 97 (SAP97) (31, $112,113)$, and CASK $(29,114)$, cytoskeletal protein tubulin $(115,116)$, a swelling-activated chloride channel (46), and signaling molecules including 14-3-3 proteins $(50,117)$ and calmodulin $(111)$. The FERM domain also mediates interaction of 4.1R with phosphatidylserine (118) and, by analogy with other members of the ERM superfamily, likely with phosphatidylinositol 4,5bisphosphate $\left(\mathrm{PIP}_{2}\right)(119)$. Importantly, several studies have established that interactions of ERM proteins with PIP $\mathrm{P}_{2}$ play a key role in their proper membrane targeting $(120,121)$. The mapping of most of the interactions described above and the crystallization of 4.1R FERM domain $(122,123)$ has unveiled the complex structure of protein scaffolds organized around this key functional domain. A $10 \mathrm{kD}$ domain, which mediates $4.1 \mathrm{R}$ interaction with spectrin and actin, is referred to as spectrin-actin binding (SAB) domain (16, 124-129). Unlike 4.1R, 4.1G and 4.1B, 4.1N is unable to form a ternary complex with spectrin and actin due to the poor conservation of its SAB domain (130). The SAB domain harbors also a nuclear localization signal $(35,131)$ whose activity is modulated by the FERM domain and the unique region U1 (34, 35, 132-134). The 22-24kD C-terminal domain (CTD) interacts with various proteins including receptors $(13,14,17,18,20,26,27)$, tight junction proteins (135) and the nuclear mitotic apparatus-associated protein $\operatorname{NuMA}(36,42)$. The four protein 4.1 genes show high homology in their FERM, SAB (except for $4.1 \mathrm{~N}$ ), and CTD domains (Figure 1), suggesting that they may share common functions.

In contrast, the unique regions U1, U2 and U3, interspersed between the conserved domains, may confer specific regulatory functions upon each 4.1 protein (Figure 1). The unique region U1 has been shown to modulate 4.1R nuclear translocation $(34,35,134)$. This region also interacts with calmodulin in a calcium-dependent manner (136) and with a centrosomal-associated protein (38). The unique region U1 also harbors a phosphorylation site for the cyclin-dependent cdc2 kinase (37), the level of phosphorylation of 4.1R varying during the cell cycle. No binding partners for the U2 and U3 unique regions have been identified so far. The unique region U2 contains a key Ser residue that is the primary substrate for protein kinase C (PKC)-dependent phosphorylation of 4.1R (137). Importantly, phosphorylation of this Ser residue leads to a decrease in $4.1 \mathrm{R}$ interaction with transmembrane protein glycophorin $\mathrm{C}$ and with spectrin and actin. Given the conservation of this Ser residue and of the surrounding amino acids in all four 4.1 proteins (Figure 3), one may anticipate that PKC-dependent phosphorylation will play a key role in regulation of $4.1 \mathrm{G}, 4.1 \mathrm{~N}$ and $4.1 \mathrm{~B}$ function as well. Importantly, the U2 region has been recently shown to confer upon $4.1 \mathrm{~B}$ its anti-proliferative properties through a still unknown mechanism (51). No function has been assigned to the U3 region yet. Of particular note, inclusion or exclusion of this alternative U3 region is a hallmark of epithelial $4.1 \mathrm{R}$ and $4.1 \mathrm{~N}$, respectively $(30,71)$. This intriguing feature likely reflects unique properties assigned to each of these protein 4.1 gene products in epithelia, including kidney. The emerging concept is that the unique regions act as modulators of protein 4.1 interactions mediated by the conserved domains and that tissue- and cell-specific splicing patterns in those regions confer upon each protein isoform unique characteristics.

\section{CYTOSKELETON AND KIDNEY ARCHITECTURE AND FUNCTION}

The nephron is composed of a monolayer of highly polarized epithelial cells that are uniquely suited to perform specific transport functions. The nonrandom distribution of membrane proteins reflects the vectorial transport functions performed by 
these cells (41-43), and the key role played by the cytoskeleton in targeting and positioning membrane proteins in these cells (7, 138-144). Importantly, while such protein complexes exist as soluble cytoplasmic scaffolds in non-confluent cells, they are targeted to cell-cell contact regions of the membrane in confluent cells, namely the lateral domain in the kidney epithelium, under the control of cell adhesion molecules (145-150). The apical membrane of the kidney epithelium is also divided into microdomains in which proteins segregate, also through interactions with the cytoskeleton (151-158). Those general concepts are likely to be applicable to most epithelia.

\subsection{Renal 4.1 proteins}

We have recently established that three members of the protein 4.1 family, i.e $4.1 \mathrm{~B}, 4.1 \mathrm{R}$ and $4.1 \mathrm{~N}$, are expressed in mouse kidney (71). We have extensively characterized the kidney-specific splicing events in each protein 4.1 gene and the consequences of these splicing events on the structure of kidney protein 4.1 isoforms. Thus, compared to the full length proteins displayed in Figure 1, kidney 4.1B and kidney 4.1R both lack the U1 region. In addition, all three proteins lack small regions at the boundary of the U2 region and the SAB domain. Moreover, kidney 4.1B lacks a small N-terminal peptide in the U3 region and kidney $4.1 \mathrm{~N}$ lacks most of the $\mathrm{U} 3$ region. Lastly, kidney $4.1 \mathrm{~B}$ bears a truncation of the very end of the C-terminal domain $(66,71,88)$. The absence of defined domains in renal 4.1 proteins likely confers upon their structure specific features that meet functional requirements in the context of the kidney epithelium. Indeed, we and others have gathered evidence for some of these kidney-specific splicing events either impairing or facilitating interactions of protein 4.1 isoforms with specific binding partners. For example, the major isoform of kidney $4.1 \mathrm{R}$ lacks a small peptide encoded by exon 16 . Since this peptide contains a spectrinbinding motif $(93,129,159,160)$ and a nuclear localization signal $(32,33,131,161)$, we predict that this kidney $4.1 \mathrm{R}$ isoform will interact weakly with spectrin and will show low level of nuclear localization. A smaller pool of kidney 4.1R containing this peptide is expected to be targeted to unique cellular compartments and/or to interact with unique binding partners. In a similar fashion, the absence of the exon 21-encoded peptide in kidney 4.1B is expected to impair kidney 4.1B interaction with proteins such as NuMA $(36,42)$. We are currently gathering evidence for the U1 region modulating the binding affinity of protein 4.1 FERM domains for selected transmembrane or membrane-associated proteins (our unpublished data). We also anticipate that inclusion of exon 17B-encoded peptide in the major kidney 4.1R isoform and exclusion of exon 17D-encoded peptide in kidney $4.1 \mathrm{~N}$ (those peptides accounting for most of the U3 region in these two 4.1 proteins, respectively) may either promote or inhibit $4.1 \mathrm{R}$ and $4.1 \mathrm{~N}$ interaction with selected renal binding partners.

An intriguing feature of renal 4.1 proteins is their mutually exclusive expression along the nephron: $4.1 \mathrm{~B}$ is primarily expressed in the proximal convoluted tubule (PCT) and the glomerulus, while 4.1R is detected in the thick ascending limb (TAL) of the loop of Henle, and $4.1 \mathrm{~N}$ in the thin limb of the loop of Henle, the distal convoluted tubule (DCT) and all regions of the collecting duct $(71,72)$. At the cellular level, all 4.1 proteins are detected in the basolateral region of the kidney epithelium. Given the extensive knowledge of transport functions dedicated to each segment of the nephron, these observations strongly suggest that each 4.1 protein is likely involved in the organization of region-specific protein scaffolds and therefore likely plays unique functions in kidney.

Interestingly, 4.1R null mice display not only the expected hematopoietic phenotype (chronic hemolytic anemia, splenomegaly, spherocytosis and reticulocytosis; (162)) but also neuro-behavioral deficits, likely resulting from the lack of 4.1R expression in cerebellum, dentate gyrus and hippocampus (70), and a renal phenotype (our unpublished data). Indeed, 4.1R null mice present with a slight urine acidification and alterations in $\mathrm{Na} / \mathrm{K}$ balance upon water deprivation. More recently, we have reported that 4.1R null red blood cells display hyperactivity of the sodium-proton exchanger NHE1 (163), of the "Gardos channel" calcium-gated potassium channel $(163,164)$ and of a potassium-chloride co-transporter $(163)$. Terada et al. have also suggested an interaction between $4.1 \mathrm{~B}$ and the sodium bicarbonate co-transporter $\mathrm{NBC} 1$ in the PCT based on electron microscopy analysis of kidney sections showing co-localization of the two proteins (72). Taken together, these recent findings provide us with interesting leads as for identifying additional ion transporters interacting with 4.1 proteins in the kidney epithelium.

\subsection{Renal ezrin}

A member of the protein 4.1 superfamily, ezrin, is expressed at high levels at the apical pole of epithelia including kidney (158) (Figure 4). Up-regulation of ezrin expression is a hallmark of major kidney diseases such as polycystic kidney disease (165) and nephrogenic diabetes insipidus (166). Ezrin, in association with PDZ domain containing protein sodium-proton exchanger regulatory factor 2 (NHERF-2), bridges the cytoskeleton and the integral membrane protein podocalyxin in podocytes (167), disorganization of this link leading to a dramatic loss in glomerular foot processes (168). A NHERF-2/podocalyxin complex has also been recently characterized in the apical region of MDCK cells undergoing polarization (169). In a similar fashion, in concert with PDZ domain-containing protein NHERF-1, ezrin has been shown to regulate sodium and phosphate reabsorption and proton secretion at the apical pole of the proximal convoluted tubule through its interaction with the sodium/phosphate co-transporter Npt2 and the sodium proton exchanger NHE3, respectively $(170,171)$. Thus, ezrin binds to the cytoplasmic domain of NHE3 but recruits also adapter and signaling molecules, i.e. NHERF-1 and cyclic AMP-dependent protein kinase (PKA) (172-174). Recruitment of PKA in the vicinity of NHE3 represents a key event in the regulation of NHE3 exchanger activity. Alterations in ezrin expression and PKA signaling have been observed in polycystic kidney disease (165).

Co-staining of mouse kidney with an anti 4.1B antibody and either an anti-ezrin or an anti-NHERF-1 antibody illustrates the mutually exclusive expression of renal 4.1 proteins and ezrin or NHERF-1 at the basolateral and apical pole of the 
kidney epithelium, respectively (Figure 4). This specialized epithelial organization may play an important role in coordination of ion transport. Indeed the level of activity of NHE3 at the apical pole of the TAL epithelium has been demonstrated to depend on the level of activity of NHE1 at the basolateral pole (175-177), the integrity of the cytoskeleton being required for this functional link to operate (178). The potential relevance of this intriguing distribution in control of cell proliferation will be discussed later in this chapter.

\subsection{Renal ankyrins}

Structure and function of renal ankyrins are discussed in another chapter of this issue. We will only emphasize here that, like renal 4.1 proteins: i) renal ankyrins are expressed as products of distinct ankyrin genes at the basolateral pole of the kidney epithelium; ii) these ankyrin gene products actually correspond to various isoforms generated by tissue-specific premRNA splicing events; iii) renal ankyrins show mutually exclusive expression along the nephron; and iv) renal ankyrins mediate proper anchorage of key ion transporters and cell adhesion molecules in the basolateral plasma membrane of the kidney epithelium.

\section{POTENTIAL FUNCTIONS FOR RENAL 4.1 PROTEINS}

As a first step to decipher the roles of 4.1 proteins in kidney structure and function, we have begun to identify potential binding partners for kidney $4.1 \mathrm{~B}$, kidney $4.1 \mathrm{R}$ and kidney $4.1 \mathrm{~N}$, through the screening of a rat kidney yeast two-hybrid system cDNA library with full length renal 4.1 proteins (71) and 4.1R CTD baits.

\subsection{Methodology}

A rat kidney yeast two-hybrid system cDNA library, cloned into the GAL4 activation domain vector pGAD3S-2X $(179,180)$, was screened for binding partners using baits corresponding to cDNAs encoding full length coding regions of the major kidney-specific isoforms of mouse 4.1N, 4.1R and 4.1B (71), or the C-terminal domain of mouse 4.1R. Baits were cloned into the LexA DNA binding domain vector pLEX12 $(179,180)$ and used for yeast transformation. Yeast transformed with each pLEX12 bait cDNA, was selected in absence of Tryptophane, then transformed with the pGAD3S-2X rat kidney cDNA library conferring upon yeast growth in absence of Leucine. Yeast was grown on triple selection plates lacking Tryptophane, Leucine and Histidine in order to select clones in which the bait of interest and putative preys interacted with each other. Such proteinprotein interactions restore a fully active GAL4 transcription factor and drive the expression of histidine selection and $\beta$ galactosidase reporter genes. Selected clones were further screened for prey interaction with kidney 4.1 protein baits based on standard X-galactose filter assay $(179,180)$. $\beta$-galactosidase positive clones were then characterized by DNA sequencing using a forward pGAD3S-2X vector specific primer. Interactions were re-confirmed in yeast co-transformed with cDNAs coding for the bait and the prey of interest. Further mapping of the regions in 4.1 proteins responsible for the identified interactions was determined after probing preys with various truncated variants of protein 4.1 FERM and CTD domains. Only relevant clones (i.e. with prey coding sequences in frame) are presented below.

\subsection{Identification of binding partners for renal 4.1 proteins}

The results of our screen to date are summarized in Table I. The predominant binding partners for kidney 4.1B (27/32 clones) and exclusive binding partners for kidney $4.1 \mathrm{~N}$ (17/17 clones) correspond to three members of the 14-3-3 family of proteins: 14-3-3theta , 14-3-3zeta, and 14-3-3beta. In contrast, these proteins represent a minor category of binding partners for kidney 4.1R (3/16 clones). Another binding partner for kidney 4.1B (5/32 clones) is pICln, a cell swelling-activated chloride channel previously reported to interact with 4.1R (46). Additional potential binding partners for kidney 4.1R include: a putative phosphatase suspected to promote cell proliferation, LRP16 (6/16 clones) $(181,182)$; two proteins involved in trafficking, SEC14L1 (1/16 clones), a mammalian homolog of yeast phosphatidylinositol/phosphatidylcholine transfer protein SEC14 (183) and the Rab GDP-dissociation inhibitor (GDI) Rab-GDIalpha (2/16 clones), a regulatory protein for small GTP-binding Rab proteins that regulates vesicle-mediated cellular transport through control of Rab GDP/GTP exchange reaction and translocation of Rab proteins between the cytosol and cell membranes (184-190). Of particular note, a small GTPase of the Rab family has been recently shown to regulate postsynaptic terminal trafficking of AMPA receptors (191), a class of receptors that has been recently reported to interact with 4.1N and PDZ domain-containing protein SAP 97 (20). Another 4.1R binding partner identified is the beta-Amyloid Precursor Protein (beta-APP) (1/16 clones), a key protein in Alzheimer's disease (AD) pathogenesis (192). 4.1R may potentially bind to a component of the protein translation machinery involved in cytoskeleton reorganization and cell transformation, i.e. elongation initiation factor 1alpha $(2 / 16$ clones) $(193,194)$. Lastly, we identified the putative tumor suppressor TMEM24 (195) (1/16 clones), a gene present in the 11q23.3 locus and frequently deleted in neuroblastomas, as a potential binding partner for $4.1 \mathrm{R}$.

While it will be important to confirm the various protein-protein interactions identified by other methodological approaches, some of them have been previously documented in the literature. As such, we will focus our discussion on the following three classes of binding partners: beta-APP, 14-3-3 proteins, and the cell swelling-activated chloride channel pICln.

\section{3. $\beta$-Amyloid Precursor Protein: a key element in progression of neuropathies and potentially epitheliopathies}

Progressive cerebral deposition of the amyloid beta-peptide (A-beta peptide) is an early and invariant feature of Alzheimer's disease (196). This peptide originates from proteolytic cleavage of the very C-terminal region of the beta-amyloid 
precursor protein (beta-APP), a widely expressed membrane-spanning glycoprotein. Normal secretion of beta-APP involves proteolytic cleavage, releasing the soluble extramembranous portion and retaining a $10 \mathrm{kD}$ C-terminal fragment in the membrane. Another proteolytic processing pathway involves reinternalization of mature beta-APP from the cell surface and its targeting to endosomes/lysosomes. Subsequent proteolytic cleavage of mature beta-APP in the late Golgi and/or endosomal compartment leads to secretion of small peptides, including the $4 \mathrm{kD}$ A-beta peptide, into the extracellular milieu. Mutations in beta-APP have been shown to promote its proteolysis, resulting in the hypersecretion of A-beta peptide by cells, a pre-symptomatic event in AD pathogenesis.

Accumulation of the A-beta peptide occurs not only in the brain but also in the abluminal basement membrane of brain microvessels (197) and, potentially, in epithelia, such as kidney. Indeed, the Madin Darby canine kidney (MDCK) cell line has been used to study beta-APP sorting and processing (196-199). A Tyr residue $\left(\mathrm{Tyr}^{653}\right)$ and the immediately adjacent residues (654-664) in the C-terminal region of beta-APP have been shown to dictate proper basolateral sorting of the protein and secretion of the A-beta peptide in MDCK cells. Importantly, basolateral secretion of A-beta peptide in MDCK cells is disturbed by alterations of intracellular $\mathrm{pH}$ and by the introduction of a mutation in beta-APP associated with familial Alzheimer's disease. However, the impact of the accumulation of the A-beta peptide in the basement membrane of epithelia, including the kidney epithelium, of $\mathrm{AD}$ patients has not been fully evaluated.

Interestingly, 4.1R has been previously reported to co-localize with neurofibrillary tangles in brain lesions of patients presenting with AD (200). It must be emphasized that, at the time of this discovery, none of the three protein 4.1 homologs were characterized and that the antibody used in this study may have possibly cross-reacted with other 4.1 homologs, since all four 4.1 proteins are expressed in brain $(66,70)$. Moreover, neurofibrillary tangles have been reported to be enriched in 14-3-3zeta (201), one of the 14-3-3 isoform identified as a binding partner for kidney 4.1B and 4.1 $\mathrm{N}$ in our screening (Table I). The observation that 4.1R null mice display some neuro-behavioral deficits (70) highlights the importance of 4.1 proteins in brain physiopathology.

Our yeast two-hybrid screening has identified the very last nine C-terminal amino acids of beta-APP $\left(\mathrm{Y}^{687} \mathrm{KFFEQMQN}\right)$ as the binding motif for 4.1R. Although this motif is located downstream of the region required for proper sorting of beta-APP and secretion of the A-beta peptide, one may speculate that 4.1R, and/or its homologs, could facilitate betaAPP anchorage in the basolateral membrane of various epithelia, including kidney. One may also speculate a role for 4.1R in basolateral secretion of the A-beta peptide since there is now clear evidence for the presence of a cytoskeletal network, including protein 4.1 homologs, on the cytoplasmic face of the Golgi apparatus and intracellular vesicles $(4,60-62,202,203)$.

Lastly, it is worth highlighting that beta-APP metabolism is stimulated by metabotropic glutamate receptors (204) and that its processing is regulated by these receptors in hippocampal neurons (205), a region of the brain where several protein 4.1 homologs are detected (66). Strikingly, metabotropic glutamate receptors have been recently reported to interact with 4.1G (17) and may potentially interact with other protein 4.1 homologs as well. Further studies are needed to determine whether protein 4.1 plays an important role in beta-APP metabolism and cell sorting in brain as well as in epithelia, and whether alterations in protein 4.1 expression either facilitate or impair the progression of beta-APP-related pathologies such as AD.

\subsection{Cell signaling: importance of $14-3-3$ proteins}

As detailed earlier, several protein-protein interactions involving protein 4.1 FERM domain have now been extensively documented (Figure 2). The recent characterization of an interaction between 4.1B FERM domain and members of the family of 14-3-3 proteins adds to the diversity of protein complexes organized around the FERM domain (117). Interestingly, 4.1R FERM domain appears to interact weakly with 143-3 proteins compared to 4.1B and 4.1G FERM domains. A Phe residue (Glu-Gln-Phe ${ }^{359}$ Glu) is necessary for 4.1B FERM domain interaction with 14-3-3epsilon, 14-3-3eta and 14-3-3gamma (50). Alignment of the four 4.1 protein FERM domains revealed that this Phe residue is conserved in $4.1 \mathrm{~B}, 4.1 \mathrm{G}$ and $4.1 \mathrm{~N}$ but not in $4.1 \mathrm{R}$ where it is replaced by a Tyr residue (Figure 2). Importantly, a Phe ${ }^{359}->$ Tyr mutation in 4.1B FERM domain impairs its interaction with 143-3 proteins, providing a mechanistic explanation for the weak interaction of 4.1 $\mathrm{R}$ with 14-3-3 proteins.

Our yeast two-hybrid system screening showed that 14-3-3 proteins are major binding partners for 4.1N. The conservation of the key $\mathrm{Phe}^{359}$ residue in 4.1N FERM domain supports further the likeliness of interactions between 4.1N and 143-3 proteins in vivo. Interestingly, the repartition of 14-3-3 clones differs between kidney $4.1 \mathrm{~N}$ and kidney 4.1B. Indeed, 14-33 beta appears as the major binding partner for kidney $4.1 \mathrm{~N}$, while 14-3-3theta is the predominant binding partner for kidney 4.1B (Table I). It is likely that variations in amino acids surrounding the canonical Phe ${ }^{359}$ residue account for preferential interactions between specific 14-3-3 and protein 4.1 isoforms. It should be noted that the subset of 14-3-3 protein isoforms (14-33 beta, theta and zeta) that we identified to interact with 4.1 proteins are different from those identified by Yu et al. (117), i.e. 143-3 epsilon, eta and gamma. This may reflect tissue-specific expression of subsets of 14-3-3 isoforms. The observations emphasized above, i.e. distinct proportion of 14-3-3 clones among binding partners for each renal 4.1 protein and distinct repartition of the 14-3-3 isoform species interacting with kidney $4.1 \mathrm{~N}$ and $4.1 \mathrm{~B}$, illustrate the functional specialization of 4.1 proteins despite the high level of conservation of key functional domains. 
The defining of an interaction between 4.1B FERM domain and a member of the 14-3-3 family of proteins, 14-3-3 epsilon (117), provides an important clue to deciphering novel mechanisms by which protein 4.1 may control cell signaling and cell proliferation. The 14-3-3 family of proteins consists of adapter proteins with multiple functions (206): regulation of cell cycle (207, 208), cell growth (209), apoptosis (210), transcription, nuclear trafficking (211), protein sorting (212, 213), signal transduction (214-219), cell polarity (220-223) and cytoskeletal structure (224-226). As disruption of interaction of some 14-3-3 proteins with 4.1B FERM domain does not impair 4.1B anti-proliferative properties (50), the precise function(s) of protein 4.1 interactions with 14-3-3 proteins still remain(s) to be defined.

For example, protein 4.1-dependent recruitment of 14-3-3 proteins could participate in regulation of activities of transmembrane proteins such as ion channels and calcium pumps (227). A recent study has unveiled a novel role for 14-3-3 proteins in mediating downregulation of Na,K-ATPase activity upon stimulation of kidney cells by dopamine, 14-3-3 proteins recruiting PI3-kinase to the site of Na,K-ATPAse endocytosis (228). The location of the 14-3-3 binding motif in 4.1 FERM domain suggests potential binding competition of 14-3-3 proteins with neighboring binding partners of 4.1 FERM domain, such as calmodulin or PDZ domain-containing proteins $(12,19,31,111)$, depending on the cell context (Figure 2). Some of these dynamic interactions could be either favored or inhibited upon cell activation. Indeed, cell activation leads to an increase in cytosolic calcium concentration and in changes in protein phosphorylation levels, both events modulating protein 4.1 interactions with its binding partners $(1,24,37,111,137,229-232)$. Finally, interactions of selected 4.1 proteins with 14-3-3 isoforms could participate in the organization of other protein complexes located in cellular compartments other than the plasma membrane (233). One of those components could be the centrosome where protein 4.1 and 14-3-3 homologs have been detected (38, 39, 42, $45,233,234)$.

\section{5.. Regulation of cell volume in response to osmotic stress: role of the cell swelling-activated chloride channel pICln 5.5.1. Mechanisms of regulation of cell volume}

Regulation of cell volume is a critical function in kidney where the epithelium environment is characterized by very different ionic compositions, depending on the segment of the nephron (235). Defective cell volume regulation leads to major nephropathies $(236,237)$. Changes in cell volume are accompanied by a reorganization of the actin cytoskeleton which is associated with membrane ion transporters, the cytoskeleton acting as both a structural network and a sensor for cell volume changes. Cells maintain a constant volume despite variations in concentrations of salts in their surroundings through either Regulatory Volume Increase (RVI), activated when cells shrink, or Regulatory Volume Decrease (RVD), activated when cells swell.

Two types of transporters mediate RVI, the Na,K,2Cl co-transporter BSC1 and the sodium proton exchangers NHE1, NHE2 and NHE4 (238-240). The reorganization of the actin cytoskeleton plays an important role in NaCl entry into the cell through activation of these membrane channels (241-243). In an hypotonic environment, cells undergo RVD as a result of a loss of $\mathrm{K}$ and $\mathrm{Cl}$, mediated by activation of a $\mathrm{K}, \mathrm{Cl}$ co-transporter (244). This ion efflux drives an outward movement of water molecules and subsequently a deerease in cell volume. An outward eurrent of chloride involving also other osmolytes, known as $\mathrm{I}_{\text {swell }}$, is involved in RVD as well (245). Several cell swelling-activated proteins have been proposed to account for the $\mathrm{I}_{\text {swell }}$ current: chloride channels C1C-2 and C1C-3, P-glycoprotein, and, importantly in the context of this review, the chloride channel pICln.

\subsubsection{Properties of the cell swelling-activated chloride channel pICln \\ 5.5.2.1. pICIn: a versatile protein}

$\mathrm{pICln}$ is an ubiquitous protein essential for cell viability (246). Its over-expression results in an increase in an outward $\mathrm{Cl}$ conductance, while its down-regulation leads to a delay and decrease in RVD (247-250). pICln therefore plays a critical role in RVD, a function that is altered in major nephropathies. pICln has been identified in reticulocytes and in young red blood cells where it accumulates in the plasma membrane through an interaction with the actin cytoskeleton (251) . In platelets, pICln associates with the alpha2-beta3 integrin and regulates platelet function (252). In kidney, pICln is detected predominantly in the cytosol of all regions of the nephron (253). In addition, it is detected at the apical pole of the epithelium in the cortex, and at both basolateral and apical poles in the medulla (253). While it is primarily present in the cytosol of resting cells, it is targeted to and inserted into plasma membrane in response to cell swelling and to diuretics $(253,254)$. Once inserted into the membrane, pICln forms a channel-like structure enabling efflux of $\mathrm{Cl}$ and other osmolytes, and therefore RVD.

The mechanism by which pICln is targeted to the membrane is still unknown (253). However, the carboxyl terminus of pICln has been shown to bind to 4.1R FERM domain, suggesting a potential involvement of 4.1R in regulation of cell volume through proper membrane anchorage of pICln (46). Moreover, pICln binds to actin (251), to a non-muscle isoform of myosin light chain (255), and to a mammalian homolog of yeast Skb1 (256). Importantly, Skb1 has been shown to control cell volume in yeast (257), through cytoskeletal rearrangement mediated by its interaction with the $\mathrm{p} 21^{\text {Cdc42/Rac }}$ activated protein kinase Shk1(258). In summary, pICln is involved in distinct cellular processes including regulation of cell volume, cell morphology, cytoskeleton architecture, cell cycle and RNA processing. Thus defining of the functional relevance of $\mathrm{pICln} / 4.1 \mathrm{interaction}$ in various cellular structures is an important goal of future studies.

\subsubsection{Characterization of $\mathrm{pICln} / 4.1$ interaction}


Protein pICln has been previously reported to interact in vitro and in vivo with 4.1R FERM domain (46). However, the recent characterization of pICln distribution in rat kidney suggests that pICln may interact with other 4.1 proteins since it is expressed in regions of the nephron where 4.1 proteins other than $4.1 \mathrm{R}$ are present (71).

Interestingly, we identified pICln as a binding partner for kidney 4.1B (Table 1). As shown in Figure 5, additional binding assays performed in yeast revealed that full length kidney 4.1R (panel A1), kidney 4.1B (panel A4), kidney 4.1N (panel B1), their respective FERM domains (panels A2, A5 and B2), as well as 4.1G FERM domain (panel A6) all interact strongly with pICln. pICln interaction with each renal 4.1 protein may be therefore functionally relevant. Moreover, serial truncations of $4.1 \mathrm{~N}$ FERM domain (panels B3-B6) enabled us to narrow down the minimal region in 4.1N FERM domain required for interaction with pICln to a peptide encompassing amino acids 162-280. A previous study reported that a slightly larger region of 4.1R FERM domain encompassing amino acids 136-283 was necessary for interaction with pICln (46). This region corresponds to the Cterminal half of the FERM domain. As proposed earlier for 14-3-3 proteins, the regulation of pICln binding to protein 4.1 FERM domain may also depend on the dynamic regulation of interactions of neighboring binding partners, in particular PDZ domain containing proteins and calmodulin (Figure 2).

Validation of the novel protein 4.1-mediated protein-protein interactions described above in vivo will rely primarily on: i) investigation of the phenotypes resulting from protein 4.1 gene silencing in relevant kidney epithelial cells, cells downregulated for protein 4.1 expression being expected to display mis-localization of binding partners, impact on 14-3-3-mediated cell signaling, metabolism of beta-APP and cell response to osmotic stress; ii) confirmation of the phenotypes unveiled through this cell based-strategy in mouse knock out models for each protein 4.1 gene as they will become available to us. Deciphering such phenotypes will be greatly facilitated by the rapid progress in microarray-based renal systems biology (259). Such an approach will enable us defining signatures as for alterations in transcriptional activity and in transduction pathways in cell lines subjected to protein 4.1 gene silencing and in protein 4.1 null mouse kidneys.

\section{PROTEIN 4.1 AND EZRIN: KEY PLAYERS IN CONTROL OF CELL PROLIFERATION}

As described earlier in this review, major kidney pathologies have been linked to ezrin over-expression. To date, none have been related to alterations in levels of protein 4.1 expression despite the presence of several members of the protein 4.1 family in the nephron. We anticipate that protein 4.1-related kidney diseases, resulting from protein 4.1-dependent defects in membrane anchorage and/or protein processing as suggested here for AD, will be characterized in the near future. Such kidney diseases will very likely include proliferative diseases. Indeed, anti-proliferative properties have been extensively documented for 4.1B $(51,53)$, and to a lesser extent for 4.1R $(48,49)$ and 4.1N $(260-262)$. Loss of heterozygosity (LOH) of 4.1B and 4.1R genes has been implicated in progression of subsets of ependymomas and meningiomas $(48,49)$. Some lung and breast carcinomas are also characterized by $\mathrm{LOH}$ and/or hypermethylation of the 4.1B gene (263). Protein 4.1B could exert its anti-proliferative effect through inhibition of protein arginine $\mathrm{N}$-methyltransferase 3 activity (52). Importantly, $4.1 \mathrm{~B}$ over-expression in proliferative neuronal cells blocks their growth (264). In a similar fashion, we have recently established that over-expression of a kidneyspecific isoform of $4.1 \mathrm{~N}$, in a kidney epithelial cell line that normally expresses this isoform, leads to cell arrest (260). Two reports have described a concomitant loss of 4.1B and E-cadherin in cell-cell contact regions upon transition from adenoma to carcinoma in pancreas and colon epithelia $(53,73)$. We therefore predict that the loss of expression of renal 4.1 proteins could lead to proliferative diseases affecting primarily regions of the nephron where each 4.1 protein is solely expressed, i.e. PCT upon loss of 4.1B expression, TAL upon loss of 4.1R expression and DCT and collecting duct upon loss of 4.1N expression.

Several proteins that have been previously described as binding partners for 4.1 proteins, and other potential binding partners that co-distribute with 4.1 proteins in the lateral domain of epithelial cells, likely participate in the formation of elaborate protein complexes responsible for cell-cell adhesion and contact inhibition. They include i) cell adhesion molecules CD44, TSLC1 and the E-cadherin/beta-catenin/alpha-catenin complex $(23,147,265,266)$; ii) the sodium-proton exchanger NHE1 (267); iii) PDZ-domain containing proteins dlg (SAP 97) and CASK (29, 31); and iv) cytoskeletal proteins such as spectrin elf (268). Alterations in activities of the small GTP-binding proteins Rac and RhoA have been proposed to initiate the disorganization of actin filaments observed in proliferative epithelia (269). Alterations in the actin cytoskeleton would in turn lead to the loss of adhesive protein complexes responsible for epithelial cell interactions through their lateral domains. It remains to be established whether the depolymerization of actin filaments is sufficient to induce disorganization of cell adhesion protein complexes or whether the loss of protein 4.1 in plasma membrane represents a key event in triggering such a disorganization.

The concept that the Four.1/Ezrin/Radixin/Moesin (FERM) domain, a highly conserved peptide among members of the protein 4.1 superfamily, mediates regulation of cell proliferation (270), has been recently challenged. Indeed, a recent study has established that the unique region $\mathrm{U} 2$ of $4.1 \mathrm{~B}$ is actually responsible for inhibition of cell growth, the FERM domain-dependent anchorage of the $\mathrm{U} 2$ region to the plasma membrane representing a necessary event for inhibition of cell proliferation (51). Other mechanisms of control of cell proliferation mediated by protein 4.1 have been proposed. Thus, $4.1 \mathrm{~N}$ nuclear translocation, occurring upon rat pheochromocytoma PC12 cell differentiation induced by nerve growth factor (261), has been shown to block cell proliferation through interaction of 4.1N CTD with the phosphatidylinositol-3 (PI-3) kinase enhancer PIKE, this interaction resulting in an inhibition of PIKE (262). A similar inhibition of PI-3 kinase through interaction of the tumor suppressor merlin 
with PIKE has been recently reported (271). It is likely that the FERM domain, the unique region U2 and the CTD domain of 4.1 proteins fulfill complementary functions in control of cell proliferation. In contrast with the loss of protein 4.1 expression observed in proliferative tissues, ezrin has been shown to be rather over-expressed upon tumorigenesis (272, 273). Furthermore, ezrin has been proposed to facilitate cell invasiveness and consequently to play a crucial role in metastasis (274-276). Ezrin's metastatic property could result from its ability to activate the PI-3 kinase/AKT survival pathway (277), Rac1- and Rasdependent pathways $(278,279)$ and the TOR/S6 kinase/4EB1 pathway $(280)$.

An intriguing observation is the dramatic change in activities of signaling molecules such as RhoA and Rac, and of adhesion molecules such as CD44 or NHE1, depending on the cell context, i.e. arrested vs. proliferative cells. This so-called cell context would actually depend in a large part on the cross-talk between the extracellular matrix and the cell (281), this cross-talk having a big impact on the characteristics of plasma membrane protein complexes interacting with the cytoskeleton. Indeed, the proliferative cellular microenvironment mimics a serum deprivation that confers increased cell motility and invasion in breast cancer cells by activating NHE1 (282). NHE1 activation and the subsequent invasive phenotype of metastatic human breast cells appears to be coordinated by a sequential RhoA/p160ROCK/p38MAPK signaling pathway gated by direct PKA-dependent phosphorylation and inhibition of RhoA. The authors suggest that serum deprivation dynamically remodels the cell and compartmentalizes the signal module described above in leading-edge pseudopodia suggesting a topographic relation of key signaling protein complexes to an invasion-specific cell structure. The disorganization of physiological protein 4.1-based cytoskeletal complexes and the resulting formation of pathological ezrin-based cytoskeletal complexes (283) could play a key role in cell proliferation and invasiveness, by altering irreversibly key signaling cues such as the PKA-gated RhoA/p160ROCK/p38MAPK signaling pathway. In support of this hypothesis, a member of the protein 4.1 superfamily, moesin, has been recently shown to participate in epithelial organization and regulation of cell proliferation through inhibition of Rho activity, thus promoting actin polymerization (284). Other pathways could be involved as well. Thus, the Drosophila protein 4.1 homolog, coracle, has been initially discovered as a dominant suppressor of the Drosophila EGF receptor homolog (28). The concept that cytoskeletal proteins can have a direct impact on cell signaling has been reinforced by an elegant study establishing a crucial role for spectrin elf, an homolog of red cell beta-spectrin, in regulation of the Transforming Growth Factor-alpha signaling pathway, through proper sorting of two key transducers of this pathway, Smad3 and Smad4 (268). These findings challenge the paradigm that members of the protein 4.1 superfamily act primarily as structural proteins by providing increasing evidence for a key role of these proteins in cell signaling through proper positioning of regulatory molecules.

The role of 4.1 proteins as tumor suppressors may also result from the ability of these proteins to maintain proper cell volume and intracellular homeostasis through the regulation of ion transporters they interact with, i.e. NHE1 and pICln. Indeed, there is now clear evidence that proliferative cells display an increase in cell volume and intracellular alkalinization (285, 286) . The loss in protein 4.1 expression observed upon epithelial tumor progression, could lead to mis-localization and deregulation of key ion transporters that normally interact with protein 4.1. Thus, NHE1 could become hyperactive in absence of protein 4.1 , resulting in an increase in $\mathrm{NaCl}$ reabsorption and in proton secretion, i.e. intracellular alkalinization. Such an hypothesis is supported by a recent observation highlighting NHE1 hyperactivity in 4.1R null red blood cells (163). Although the functional relevance of an interaction between another member of the protein 4.1 superfamily, ezrin, and NHE1 has been extensively documented in fibroblasts, the occurrence of this interaction in normal epithelia is unlikely given the mutually exclusive expression of NHE1 and ezrin, at the basolateral and apical poles, respectively $(165,267)$. Based on protein 4.1 and NHE1 codistribution in the lateral domain of epithelia, on the presence of a potential juxta-membrane protein 4.1 binding motif (VKKKQ) in NHE1 cytoplasmic domain and on functional alterations of NHE1 in 4.1R null red blood cells (163), we are currently investigating whether 4.1R and its homologs are indeed relevant binding partners for NHE1 in kidney epithelium. We speculate that, upon loss of cell polarity and loss of protein 4.1 expression, an interaction between NHE1 and ezrin would be favored and could potentially participate in tumor progression (Figure 6). Dissecting the protein complexes organized around ezrin and transmembrane proteins NHE1 and CD44 would likely lead to an understanding of how ezrin promotes cell motility (287). A major challenge will be to understand the mechanisms governing distinct cellular distribution and opposite effects on cell proliferation for protein 4.1 and ezrin, despite some structural and functional homology of these two cytoskeletal proteins.

\section{CONCLUSION}

Much remains to be done to define the actual involvement of cytoskeletal protein 4.1- and ezrin-based networks in kidney function and the mechanisms by which they fulfill these functions in various parts of the nephron. In particular, we need to further our understanding of the relationships between cytoskeleton-dependent positioning of key transmembrane and adapter proteins and cell signaling wiring and of the consequences of alterations of the cytoskeleton on those processes. The generation of mouse knock out models for each of the four protein 4.1 genes will be instrumental in evaluating the impact of a selective loss of protein 4.1 expression in vivo and in assessing the occurrence of compensatory mechanisms through up-regulation of non targeted 4.1 proteins and/or other members of the protein 4.1 superfamily, such as the ERM proteins.

A major challenge of future investigation will be to decipher the mechanisms responsible for the highly selective expression of spliceforms arising from closely related cytoskeletal protein genes in specialized regions of a given tissue and to evaluate the physiological implications of such an elaborate sorting. Such mechanisms likely involve a well orchestrated network of tissue- and cell-specific transcriptional and signaling events. Their characterization will represent a breakthrough in the 
cytoskeleton field and will without a doubt further our understanding of the functional links between tissue architecture and physiology. As emphasized by Mohler and Bennett in the chapter related to ankyrins, it will be crucial in that respect to choose appropriate cell and animal models to decipher this fascinating machinery.

\section{ACKNOWLEDGEMENTS}

This work was supported by NIH grants DK56355 to Philippe Gascard and DK32094 to Narla Mohandas. We thank Drs. Sharon Krauss and William Jagust (Life Sciences Division, Lawrence Berkeley National Laboratory, Berkeley, CA) for their critical evaluation of the manuscript and Drs. John Conboy and Joel Chasis (Lawrence Berkeley National Laboratory) for their invaluable support.

\section{REFERENCES}

1. Cohen CM \& P Gascard: Regulation and post-translational modification of erythrocyte membrane and membrane-skeletal proteins. Semin Hematol 29, 244-292 (1992)

2. Tsukita S \& S Yonemura: Cortical actin organization: lessons from ERM (ezrin/radixin/moesin) proteins, $J$ Biol Chem 274 , 34507-34510 (1999)

3. Fehon RG, D LaJeunesse, R Lamb, BM McCartney, L Schweizer \& RE Ward: Functional studies of the protein 4.1 family of junctional proteins in Drosophila. Soc Gen Physiol Ser 52, 149-159 (1997)

4. Gascard P \& N Mohandas: New insights into functions of erythroid proteins in nonerythroid cells. Curr Opin Hematol 7, 123$129(2000)$

5. Goodman SR, K Shiffer, DB Coleman \& CF Whitfield : Erythrocyte membrane skeletal protein 4.1: a brief review. Prog Clin Biol Res 165, 415-439 (1984)

6. Hoover KB \& PJ Bryant: The genetics of the protein 4.1 family: organizers of the membrane and cytoskeleton. Curr Opin Cell Biol 12, 229-234 (2000)

7. Bretscher A, D Chambers, R Nguyen \& D Reczek: ERM-Merlin and EBP50 protein families in plasma membrane organization and function. Annu Rev Cell Dev Biol 16, 113-143 (2000)

8. Bretscher A, K Edwards \& RG Fehon: ERM proteins and merlin: integrators at the cell cortex. Nat Rev Mol Cell Biol 3, 586$599(2002)$

9. Mohandas N, L Peters, J Barker \& P Gascard : What do mouse gene knockouts tell us about the structure and function of the red cell membrane? In: Red Cell Membrane Disorders - Baillieres Best Practice \& Research Clinical Haematology.. Eds: Tanner MJA \& DJ Anstee. Harcourt Publishers Ltd. London, UK. 12, 605-620 (1999)

10. Conboy J G, R Shitamoto, M Parra, R Winardi, A Kabra, J Smith \& N Mohandas: Hereditary elliptocytosis due to both qualitative and quantitative defects in membrane skeletal protein 4.1. Blood 78, 2438-2443 (1991)

11. Conboy J, N Mohandas, G Tchernia \& YW Kan: Molecular basis of hereditary elliptocytosis due to protein 4.1 deficiency. $N$ Engl J Med. 315, 680-685 (1986)

12. Alloisio N, N Dalla Venezia, A Rana, K Andrabi, P Texier, F Gilsanz, JP Cartron, J Delaunay \& AH Chishti: Evidence that red blood cell protein p55 may participate in the skeleton-membrane linkage that involves protein 4.1 and glycophorin C. Blood. $82,1323-1327(1993)$

13. Binda AV, N Kabbani, R Lin \& R Levenson: D2 and D3 dopamine receptor cell surface localization mediated by interaction with protein 4.1N. Mol Pharmacol 62, 507-513 (2002)

14. Fukatsu K, H Bannai, S Zhang, H Nakamura, T Inoue \& K Mikoshiba: Lateral diffusion of inositol 1,4,5-trisphosphate receptor type 1 is regulated by actin filaments and 4.1N in neuronal dendrites. J Biol Chem 279, 48976-48982 (2004) 
15. Lamb RS, RE Ward, L Schweizer \& RG Fehon: Drosophila coracle, a member of the protein 4.1 superfamily, has essential structural functions in the septate junctions and developmental functions in embryonic and adult epithelial cells. Mol Biol Cell 9, 3505-3519 (1998)

16. Lorenzo F, N Dalla Venezia, L Morle, F Baklouti, N Alloisio, MT Ducluzeau, L Roda., P Lefrancois \& J Delaunay: Protein 4.1 deficiency associated with an altered binding to the spectrin-actin complex of the red cell membrane skeleton. $J$ Clin Invest 94, 1651-1656 (1994)

17. Lu D, H Yan, T Othman \& SA Rivkees: Cytoskeletal protein $4.1 \mathrm{G}$ is a binding partner of the metabotropic glutamate receptor subtype 1 alpha.J Neurosci Res 78, 49-55 (2004)

18. Lu D, H Yan, T Othman, CP Turner, T Woolf \& SA Rivkees,: Cytoskeletal protein 4.1G binds to the third intracellular loop of the A1 adenosine receptor and inhibits receptor action. Biochem J 377, 51-59 (2004)

19. Marfatia SM, RA Lue, D Branton \& AH Chishti: In vitro binding studies suggest a membrane-associated complex between erythroid p55, protein 4.1, and glycophorin C. J Biol Chem 269, 8631-8634 (1994)

20. Coleman SK, C Cai, DG Mottershead, JP Haapalahti \& K Keinanen:Surface expression of GluR-D AMPA receptor is dependent on an interaction between its C-terminal domain and a 4.1 protein. J Neurosci 23, 798-806 (2003)

21. Moriniere M, L Ribeiro, N Dalla Venezia, M Deguillien, P Maillet, T Cynober, F Delhommeau, H Almeida, G Tamagnini, J Delaunay \& F Baklouti: Elliptocytosis in patients with C-terminal domain mutations of protein 4.1 correlates with encoded messenger RNA levels rather than with alterations in primary protein structure. Blood. 95, 1834-1841. (2000)

22. Morle L, B Pothier, N Alloisio, MT Ducluzeau, S Marques, G Olim, J Martins e Silva, C Feo, M Garbarz, I Chaveroche et al.: Red cell membrane alteration involving protein 4.1 and protein 3 in a case of recessively inherited haemolytic anaemia. Eur $J$ Haematol 38, 447-455 (1987)

23. Nunomura W, Y Takakuwa, R Tokimitsu, SW Krauss, M Kawashima \& N Mohandas: Regulation of CD44-protein 4.1 interaction by $\mathrm{Ca} 2+$ and calmodulin. Implications for modulation of CD44-ankyrin interaction. J Biol Chem 272, 30322-30328 (1997)

24. Nunomura W, Y Takakuwa, M Parra, J Conboy \& N Mohandas: Regulation of protein 4.1R, p55, and glycophorin C ternary complex in human erythrocyte membrane. J Biol Chem 275, 24540-24546. (2000)

25. Reid ME, Y Takakuwa, J Conboy, G Tchernia \& N Mohandas: Glycophorin C content of human erythrocyte membrane is regulated by protein 4.1. Blood 75, 2229-2234 (1990)

26. Zhang S, A Mizutani, C Hisatsune, T Higo, H Bannai, T Nakayama, M Hattori \& K Mikoshiba: Protein 4.1N is required for translocation of inositol 1,4,5-trisphosphate receptor type 1 to the basolateral membrane domain in polarized Madin-Darby canine kidney cells. J Biol Chem 278, 4048-4056. (2003)

27. Ralston KJ, SL Hird, X Zhang, JL Scott, B Jin, RF Thorne, MC Berndt, AW Boyd \& GF Burns: The LFA-1-associated molecule PTA-1 (CD226) on T cells forms a dynamic molecular complex with protein 4.1G and human discs large. $J$ Biol Chem $279,33816-33828(2004)$

28. Fehon RG, IA Dawson \& S Artavanis-Tsakonas: A Drosophila homologue of membrane-skeleton protein 4.1 is associated with septate junctions and is encoded by the coracle gene. Development 120, 545-557 (1994)

29. Cohen AR, DF Woods, SM Marfatia, Z Walther, AH Chishti, JM Anderson \& DF Wood: Human CASK/LIN-2 binds syndecan-2 and protein 4.1 and localizes to the basolateral membrane of epithelial cells. J Cell Biol 142, 129-138 (1998)

30. Schischmanoff PO, P Yaswen, MK Parra, G Lee, JA Chasis, N Mohandas \& JG Conboy: Cell shape-dependent regulation of protein 4.1 alternative pre-mRNA splicing in mammary epithelial cells. J Biol Chem 272, 10254-10259 (1997)

31. Hanada T, A Takeuchi, G Sondarva \& AH Chishti: Protein 4.1-mediated membrane targeting of human discs large in epithelial cells. J Biol Chem 278, 34445-34450 (2003)

32. Correas I: Characterization of isoforms of protein 4.1 present in the nucleus. Biochem J 279, 581-585 (1991) 
33. De Carcer G, MJ Lallena \& I Correas: Protein 4.1 is a component of the nuclear matrix of mammalian cells. Biochem $J 312$, 871-877 (1995)

34. Gascard P, G Lee, L Coulombel, I Auffray, M Lum, M Parra, JG Conboy, N Mohandas \& JA Chasis: Characterization of multiple isoforms of protein 4.1R expressed during erythroid terminal differentiation. Blood. 92, 4404-4414 (1998)

35. Gascard P, W Nunomura, G Lee, LD Walensky, SW Krauss, Y Takakuwa, JA Chasis, N Mohandas \& JG Conboy: Deciphering the nuclear import pathway for the cytoskeletal red cell protein 4.1R. Mol Biol Cell 10, 1783-1798 (1999)

36. Huang SC, R Jagadeeswaran, ES Liu\& EJ Jr. Benz: Protein 4.1R, a microtubule-associated protein involved in microtubule aster assembly in mammalian mitotic extract. J Biol Chem 279, 34595-34602 (2004)

37. Huang SC, ES Liu, SH Chan, ID Munagala, HT Cho, R Jagadeeswaran \& EJ Jr. Benz: Mitotic regulation of protein 4.1R involves phosphorylation by cdc2 kinase. Mol Biol Cell 16, 117-127 (2005)

38. Hung LY, CJ Tang \& TK Tang: Protein 4.1 R-135 interacts with a novel centrosomal protein (CPAP) which is associated with the gamma-tubulin complex. Mol Cell Biol 20, 7813-7825 (2000)

39. Krauss SW, JA Chasis, C Rogers, N Mohandas, G Krockmalnic \& S Penman: Structural protein 4.1 is located in mammalian centrosomes. Proc Natl Acad Sci U S A 94, 7297-7302 (1997)

40. Krauss SW, CA LarabellA, S Lockett, P Gascard, S Penman, N Mohandas \& JA Chasis: Structural protein 4.1 in the nucleus of human cells: dynamic rearrangements during cell division. J Cell Biol 137, 275-289. (1997)

41. Krauss SW, C Chen, S Penman \& R Heald: Nuclear actin and protein 4.1: essential interactions during nuclear assembly in vitro. Proc Natl Acad Sci U S A 100, 10752-10757 (2003)

42. Krauss SW, G Lee, JA Chasis, N Mohandas \& R Heald: Two protein 4.1 domains essential for mitotic spindle and aster microtubule dynamics and organization in vitro. J Biol Chem 279, 27591-27598 (2004)

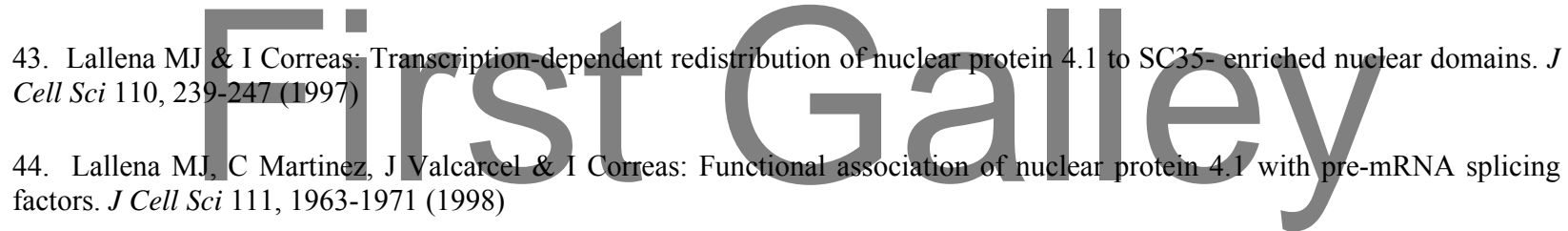

45. Perez-Ferreiro CM, I Vernos \& I Correas: Protein 4.1R regulates interphase microtubule organization at the centrosome. $J$ Cell Sci 117, 6197-6206. (2004)

46. Tang CJ \& TK Tang : The 30-kD domain of protein 4.1 mediates its binding to the carboxyl terminus of pICln, a protein involved in cellular volume regulation. Blood. 92, 1442-1447 (1998)

47. Jiang W, ME Roemer \& IF Newsham:The tumor suppressor DAL-1/4.1B modulates protein arginine N-methyltransferase 5 activity in a substrate-specific manner. Biochem Biophys Res Commun 329, 522-530 (2005)

48. Rajaram V, DH Gutmann, SK Prasad, DB Mansur, \& A Perry: Alterations of protein 4.1 family members in ependymomas: a study of 84 cases. Mod Pathol in press (2005)

49. Robb VA, W Li, P Gascard, A Perry, N Mohandas \& DH Gutmann: Identification of a third Protein 4.1 tumor suppressor, Protein 4.1R, in meningioma pathogenesis. Neurobiol Dis 13, 191-202 (2003)

50. Robb VA, W Li \& DH Gutmann: Disruption of 14-3-3 binding does not impair Protein 4.1B growth suppression. Oncogene 23, 3589-3596 (2004)

51. Robb VA, MA Gerber, EK Hart-Mahon \& DH Gutmann: Membrane localization of the U2 domain of Protein 4.1B is necessary and sufficient for meningioma growth suppression. Oncogene 24, 1946-1957 (2005) 
52. Singh V, TB Miranda, W Jiang, A Frankel, ME Roemer, VA Robb, DH Gutmann, HR Herschman, S Clarke \& IF Newsham: DAL-1/4.1B tumor suppressor interacts with protein arginine N-methyltransferase 3 (PRMT3) and inhibits its ability to methylate substrates in vitro and in vivo. Oncogene 23, 7761-7771 (2004)

53. Terada N, N Ohno, H Yamakawa, T Baba, Y Fujii, G Christofori, O Ohara \& S Ohno: Protein 4.1B in mouse islets of Langerhans and beta-cell tumorigenesis. Histochem Cell Biol 120, 277-283 (2003)

54. Takakuwa Y : Protein 4.1, a multifunctional protein of the erythrocyte membrane skeleton: structure and functions in erythrocytes and nonerythroid cells. Int J Hematol 72, 298-309 (2000)

55. Chishti AH, AC Kim, SM Marfatia, M Lutchman, M Hanspal, H Jindal, SC Liu, PS Low, GA Rouleau, N Mohandas, JA Chasis, JG Conboy, P Gascard, Takakuwa, Y., SC Huang, EJ Jr Benz, A Bretscher, RG Fehon, JF Gusella, V Ramesh, F Solomon, VT Marchesi, S Tsukita, M Arpin, D Louvard, NK Tonks, JM Anderson, AS Fanning, PJ Bryant, DF Woods \& KB Hoover xx: The FERM domain: a unique module involved in the linkage of cytoplasmic proteins to the membrane (letter). Trends Biochem Sci 23, 281-282 (1998)

56. Conboy J, YW Kan, SB Shohet \& N Mohandas: Molecular cloning of protein 4.1, a major structural element of the human erythrocyte membrane skeleton. Proc Natl Acad Sci U S A. 83, 9512-9516 (1986)

57. Conboy J: Molecular cloning and characterization of the gene coding for red cell membrane skeletal protein 4.1. Biorheology 24, 673-687 (1987)

58. Conboy JG : Structure, function, and molecular genetics of erythroid membrane skeletal protein 4.1 in normal and abnormal red blood cells. Semin Hematol 30, 58-73 (1993)

59. Huang JP, CJ Tang, GH Kou, VT Marchesi, EJ Jr Benz \& TK Tang: Genomic structure of the locus encoding protein 4.1. Structural basis for complex combinational patterns of tissue-specific alternative RNA splicing. J Biol Chem 268, $3758-3766$ (1993)

60. Parra M, P Gascard, LD Walensky, SH Snyder, N Mohandas \& JG Conboy: Cloning and characterization of 4.1G (EPB41L2), a new member of the skeletal protein 4.1 (EPB41) gene family. Genomics 49, 298-306 (1998)

61. Walensky LD, P Gascard, ME Fields, S Blackshaw, JG Conboy, N Mohandas \& SH Snyder: The 13-kD FK506 binding protein, FKBP13, interacts with a novel homologue of the erythrocyte membrane cytoskeletal protein 4.1, J Cell Biol 141, 143$153(1998)$

62. Walensky LD, S Blackshaw, D Liao, CC Watkins, HU Weier, M Parra, RL Huganir, JG Conboy, N Mohandas \& SH Snyder: A novel neuron-enriched homolog of the erythrocyte membrane cytoskeletal protein 4.1. J Neurosci 19, 6457-6467 (1999)

63. Kim AC, C Van Huffel, M Lutchman \& AH Chishti: Radiation hybrid mapping of EPB41L1, a novel protein 4.1 homologue, to human chromosome 20q11.2-q12. Genomics. 49, 165-166 (1998)

64. Yamakawa H, R Ohara, D Nakajima, M Nakayama \& O Ohara.:Molecular characterization of a new member of the protein 4.1 family (brain 4.1) in rat brain. Brain Res Mol Brain Res 70, 197-209 (1999)

65. Ohara R, H Yamakawa, M Nakayama, S Yuasa \& O Ohara: Cellular and subcellular localization of a newly identified member of the protein 4.1 family, brain 4.1, in the cerebellum of adult and postnatally developing rats. Brain Res Dev Brain Res $117,127-138(1999)$

66. Parra M, P Gascard, LD Walensky, JA Gimm, S Blackshaw, N Chan, Y Takakuwa, T Berger, G Lee, JA Chasis, SH Snyder, N Mohandas \& JG Conboy: Molecular and functional characterization of protein 4.1B, a novel member of the protein 4.1 family with high level, focal expression in brain, J Biol Chem 275, 3247-3255 (2000)

67. Ohara R, H Yamakawa, M Nakayama \& O Ohara: Type II brain 4.1 (4.1B/KIAA0987), a member of the protein 4.1 family, is localized to neuronal paranodes. Brain Res Mol Brain Res 85, 41-52 (2000)

68. Yamakawa, H. \& Ohara, O. :Comparison of mRNA and protein levels of four members of the protein 4.1 family: the type II brain 4.1/4.1B/KIAA0987 is the most predominant member of the protein 4.1 family in rat brain. Gene 248, 137-145 (2000) 
69. Peters LL, HU Weier, LD Walensky, SH Snyder, M Parra, N Mohandas \& JG Conboy: Four paralogous protein 4.1 genes map to distinct chromosomes in mouse and human. Genomics 54, 348-350. (1998)

70. Walensky LD, ZT Shi, S Blackshaw, AC DeVries, GE Demas, P Gascard, RJ Nelson, JG Conboy, EM Rubin, SH Snyder \& N Mohandas: Neurobehavioral deficits in mice lacking the erythrocyte membrane cytoskeletal protein 4.1. Curr Biol 8, 12691272. (1998)

71. Ramez M, M Blot-Chabaud, F Cluzeaud, S Chanan, M Patterson, LD Walensky, S Marfatia, AJ Baines, JA Chasis, JG Conboy, N Mohandas \& P Gascard: Distinct distribution of specific members of protein 4.1 gene family in the mouse nephron. Kidney Int 63, 1321-1337 (2003)

72. Terada N, N Ohno, H Yamakawa, G Seki, Y Fujii, T Baba, O Ohara \& S Ohno: Immunoelectron microscopic localization of protein 4.1B in proximal S1 and S2 tubules of rodent kidneys. Med Electron Microsc 37, 45-51. (2004)

73. Terada N, N Ohno, H Yamakawa, T Baba, Y Fujii, O Ohara \& S Ohno: Immunolocalization of protein 4.1B in the rat digestive system. J Mol Histol 35, 347-353 (2004)

74. Terada N, N Ohno, H Yamakawa, T Baba, Y Fujii, O Ohara \& S Ohno: Protein 4.1B localizes on unmyelinated axonal membranes in the mouse enteric nervous system. Neurosci Lett. 366, 15-17 (2004)

75. Terada N, N Ohno, H Yamakawa, T Baba, Y Fujii, Z Zea, O. Ohara \& S. Ohno: Immunohistochemical study of protein 4.1B in the normal and W/W(v) mouse seminiferous epithelium. J Histochem Cytochem 52, 769-777. (2004)

76. Granger BL \& E Lazarides: Membrane skeletal protein 4.1 of avian erythrocytes is composed of multiple variants that exhibit tissue-specific expression. Cell 37, 595-607 (1984)

77. Granger BL \& E Lazarides: Appearance of new variants of membrane skeletal protein 4.1 during terminal differentiation of avian erythroid and lenticular cells. Nature 313, 238-241 (1985)

78. Conboy J: The role of alternative pre-mRNA splicing in regulating the structure and function of skeletal protein 4.1. Proc Soc Exp Biol Med. 220, 73-78 (1999)

79. McGuire M, BL Smith \& P Agre: Distinct variants of erythrocyte protein 4.1 inherited in linkage with elliptocytosis and Rh type in three white families. Blood. 72, 287-293 (1988)

80. Conboy JG, JY Chan, JA Chasis, YW Kan \& N Mohandas: Tissue- and development-specific alternative RNA splicing regulates expression of multiple isoforms of erythroid membrane protein 4.1. J Biol Chem 266, 8273-8280 (1991)

81. Conboy JG, J Chan, N Mohandas \& YW Kan: Multiple protein 4.1 isoforms produced by alternative splicing in human erythroid cells. Proc Natl Acad Sci U S A 85, 9062-9065 (1988)

82. Huang SC, F Baklouti, TK Tang \& EJ Benz: Differential utilization of translation initiation sites in alternatively spliced mRNAs arising from the protein 4.1 gene. Trans Assoc Am Physicians 105, 165-171 (1992)

83. Chasis JA, L Coulombel, J Conboy, S McGee, K Andrews, YW Kan \& N Mohandas: Differentiation-associated switches in protein 4.1 expression. Synthesis of multiple structural isoforms during normal human erythropoiesis. J Clin Invest 91, 329-338 (1993)

84. Chasis JA, L Coulombel, S McGee, G Lee, G Tchernia, J Conboy \& N Mohandas: Differential use of protein 4.1 translation initiation sites during erythropoiesis: implications for a mutation-induced stage-specific deficiency of protein 4.1 during erythroid development. Blood. 87, 5324-5331 (1996)

85. Ngai J, JH Stack, RT Moon \& E Lazarides: Regulated expression of multiple chicken erythroid membrane skeletal protein 4.1 variants is governed by differential RNA processing and translational control. Proc Natl Acad Sci U S A 84, 4432-4436 (1987)

86. Baklouti F, SC Huang, TJ Vulliamy, J Delaunay \& EJ Jr Benz: Organization of the human protein 4.1 genomic locus: new insights into the tissue-specific alternative splicing of the pre-mRNA. Genomics 39, 289-302 (1997) 
87. Yang G, SC Huang, JY Wu \& EJ Jr Benz: An erythroid differentiation-specific splicing switch in protein 4.1R mediated by the interaction of SF2/ASF with an exonic splicing enhancer. Blood. 105, 2146-2153 (2005)

88. Gascard P, MK Parra, Z Zhao, VR Calinisan, W Nunomura, SA Rivkees, N Mohandas \& JG Conboy: Putative tumor suppressor protein $4.1 \mathrm{~B}$ is differentially expressed in kidney and brain via alternative promoters and 5 ' alternative splicing, Biochim Biophys Acta 1680, 71-82 (2004)

89. Tang TK, TL Leto, I Correas, MA Alonso, VT Marchesi \& EJ Jr Benz: Selective expression of an erythroid-specific isoform of protein 4.1. Proc Natl Acad Sci U S A 85, 3713-3717 (1988)

90. Tang TK, TL Leto, VT Marchesi \& EJ Jr Benz: Expression of specific isoforms of protein 4.1 in erythroid and nonerythroid tissues. Adv Exp Med Biol 241, 81-95 (1988)

91. Tang TK, Z Qin, T Leto, VT Marchesi \& EJ Jr Benz: Heterogeneity of mRNA and protein products arising from the protein 4.1 gene in erythroid and nonerythroid tissues. J Cell Biol 110, 617-624. (1990)

92. Parra M, S Gee, N Chan, D Ryaboy, I Dubchak, N Mohandas, PD Gascard \& JG Conboy: Differential domain evolution and complex RNA processing in a family of paralogous EPB41 (protein 4.1) genes facilitate expression of diverse tissue-specific isoforms. Genomics 84, 637-646 (2004)

93. Winardi R, D Discher, C Kelley, L Zon, K Mays, N Mohandas \& JG Conboy: Evolutionarily conserved alternative premRNA splicing regulates structure and function of the spectrin-actin binding domain of erythroid protein 4.1. Blood. 86, 4315$4322(1995)$

94. Leto TL \& VT Marchesi: A structural model of human erythrocyte protein 4.1. J Biol Chem 259, 4603-4608 (1984)

95. Jons T \& D Drenckhahn: Identification of the binding interface involved in linkage of cytoskeletal protein 4.1 to the erythrocyte anion exchanger. Embo J 11, 2863-2867 (1992)

96. Pasternack GR, RA Anderson, TL Leto \& VT Marchesi: Interactions between protein 4.1 and band 3. An alternative binding site for an element of the membrane skeleton. J Biol Chem 260, 3676-3683 (1985)

97. An XL, Y Takakuwa, W Nunomura, S Manno \& N Mohandas: Modulation of band 3-ankyrin interaction by protein 4.1. Functional implications in regulation of erythrocyte membrane mechanical properties. J Biol Chem 271, 33187-33191 (1996)

98. Workman RF \& PS Low: Effect of purification protocol on the functional properties of erythrocyte membrane protein 4.1. Protein Expr Purif 12, 100-104 (1998)

99. Chasis JA \& N Mohandas: Red blood cell glycophorins. Blood. 80, 1869-1879. (1992)

100. Anderson RA \& VT Marchesi: Regulation of the association of membrane skeletal protein 4.1 with glycophorin by a polyphosphoinositide. Nature 318, 295-298. (1985)

101. Gascard P, T Pawelczyk, JM Lowenstein \& CM Cohen: The role of inositol phospholipids in the association of band 4.1 with the human erythrocyte membrane. Eur J Biochem 211, 671-681. (1993)

102. Gascard P \& CM Cohen: Absence of high-affinity band 4.1 binding sites from membranes of glycophorin C- and Ddeficient (Leach phenotype) erythrocytes. Blood. 83, 1102-1108. (1994)

103. Reid ME, Y Takakuwa, G Tchernia, RH Jensen, JA Chasis \& N Mohandas: Functional role for glycophorin C and its interaction with the human red cell membrane skeletal component, protein 4.1. Prog Clin Biol Res 319, 553-571 (1989)

104. Pinder JC, A Chung, ME Reid \& WB Gratzer: Membrane attachment sites for the membrane cytoskeletal protein 4.1 of the red blood cell. Blood. 82, 3482-3488 (1993)

105. Chang SH \& PS Low: Regulation of the glycophorin C-protein 4.1 membrane-to-skeleton bridge and evaluation of its contribution to erythrocyte membrane stability. J Biol Chem 276, 22223-22230 (2001) 
106. Zhou Y, G Du, X Hu, S Yu, Y Liu, Y Xu, X Huang, J Liu, B Yin, M Fan, X Peng, B Qiang \& J Yuan: Nectin-like molecule 1 is a protein $4.1 \mathrm{~N}$ associated protein and recruits protein $4.1 \mathrm{~N}$ from cytoplasm to the plasma membrane. Biochim Biophys Acta 1669, 142-154 (2005)

107. Menegoz M, P Gaspar, M Le Bert, T Galvez, F Burgaya, C Palfrey, P Ezan, F Arnos \& JA Girault :Paranodin, a glycoprotein of neuronal paranodal membranes. Neuron. 19, 319-331 (1997)

108. Girault JA, K Oguievetskaia, M Carnaud, N Denisenko-Nehrbass \& L Goutebroze: Transmembrane scaffolding proteins in the formation and stability of nodes of Ranvier. Biol Cell 95, 447-452 (2003)

109. Gollan L, H Sabanay, S Poliak, EO Berglund, B Ranscht \& E Peles: Retention of a cell adhesion complex at the paranodal junction requires the cytoplasmic region of Caspr. J Cell Biol 157, 1247-1256 (2002)

110. Denisenko-Nehrbass N, K Oguievetskaia, L Goutebroze, T Galvez, H Yamakawa, O Ohara, M Carnaud \& JA Girault: Protein 4.1B associates with both Caspr/paranodin and Caspr2 at paranodes and juxtaparanodes of myelinated fibres. Eur $J$ Neurosci 17, 411-416 (2003)

111. Nunomura W, Y Takakuwa, M Parra, JG Conboy \& N Mohandas: Ca(2+)-dependent and Ca(2+)-independent calmodulin binding sites in erythrocyte protein 4.1. Implications for regulation of protein 4.1 interactions with transmembrane proteins. $J$ Biol Chem 275, 6360-6367 (2000)

112. Wu H, SM Reuver, S Kuhlendahl, WJ Chung \& CC Garner: Subcellular targeting and cytoskeletal attachment of SAP97 to the epithelial lateral membrane. J Cell Sci 111, 2365-2376 (1998)

113. Rumbaugh G, GM Sia, CC Garner \& RL Huganir: Synapse-associated protein-97 isoform-specific regulation of surface AMPA receptors and synaptic function in cultured neurons. $J$ Neurosci 23, 4567-4576 (2003)

114. Biederer T \& TC Sudhof: CASK and protein 4.1 support F-actin nucleation on neurexins. J Biol Chem 276, 47869-47876 (2001)

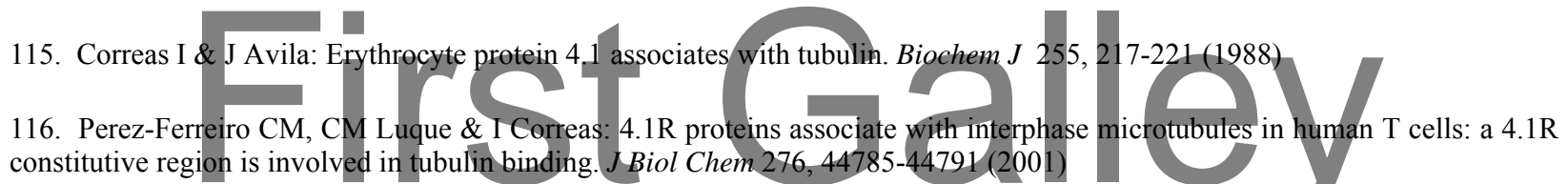

117. Yu T, VA Robb, V Singh, DH Gutmann \& IF Newsham: The 4.1/ezrin/radixin/moesin domain of the DAL-1/Protein 4.1B tumour suppressor interacts with 14-3-3 proteins. Biochem J. 365, 783-789 (2002)

118. An XL, Y Takakuwa, S Manno, BG Han, P Gascard \& N Mohandas: Structural and functional characterization of protein 4.1R-phosphatidylserine interaction: potential role in 4.1R sorting within cells. J Biol Chem. 276, 35778-35785 (2001)

119. Hamada K, T Shimizu, T Matsui, S Tsukita \& T Hakoshima: Structural basis of the membrane-targeting and unmasking mechanisms of the radixin FERM domain. Embo $J$ 19, 4449-4462 (2000)

120. Barret C, C Roy, P Montcourrier, P Mangeat \& V Niggli: Mutagenesis of the phosphatidylinositol 4,5-bisphosphate (PIP(2)) binding site in the NH(2)-terminal domain of ezrin correlates with its altered cellular distribution. J Cell Biol 151, 1067$1080(2000)$

121. Bompard G, M Martin, C Roy, F Vignon \& G Freiss: Membrane targeting of protein tyrosine phosphatase PTPL1 through its FERM domain via binding to phosphatidylinositol 4,5-biphosphate. J Cell Sci 116, 2519-2530 (2003)

122. Han BG, W Nunomura, H Wu, N Mohandas \& BK Jap: Crystallization and preliminary X-ray crystallographic analysis of the $30 \mathrm{kDa}$ membrane-binding domain of protein 4.1 from human erythrocytes. Acta Crystallogr D Biol Crystallogr 56, 187-188 (2000)

123. Han BG, W Nunomura, Y Takakuwa, N Mohandas \& BK Jap: Protein 4.1R core domain structure and insights into regulation of cytoskeletal organization. Nat Struct Biol 7, 871-875 (2000) 
124. Tchernia G, N Mohandas \& SB Shohet: Deficiency of skeletal membrane protein band 4.1 in homozygous hereditary elliptocytosis. Implications for erythrocyte membrane stability. J Clin Invest 68, 454-460 (1981)

125. Wolfe LC, KM John, JC Falcone, AM Byrne \& SE Lux: A genetic defect in the binding of protein 4.1 to spectrin in a kindred with hereditary spherocytosis. $N$ Engl J Med. 307, 1367-1374 (1982)

126. Correas I, DW Speicher \& VT Marchesi.: Structure of the spectrin-actin binding site of erythrocyte protein 4.1. J Biol Chem 261, 13362-13366 (1986)

127. Correas I, TL Leto, DW Speicher \& VT Marchesi: Identification of the functional site of erythrocyte protein 4.1 involved in spectrin-actin associations. J Biol Chem 261, 3310-3315 (1986)

128. Pinder JC, V Ohanian, \& WB Gratzer: Spectrin and protein 4.1 as an actin filament capping complex. FEBS Lett 169, 161$164(1984)$

129. Schischmanoff PO, R Winardi, DE Discher, MK Parra, SE Bicknese, HE Witkowska, JG Conboy \& N Mohandas: Defining of the minimal domain of protein 4.1 involved in spectrin- actin binding. J Biol Chem 270, 21243-21250 (1995)

130. Gimm JA, X An, W Nunomura \& N Mohandas: Functional characterization of spectrin-actin-binding domains in 4.1 family of proteins. Biochemistry 41, 7275-7282 (2002)

131. Luque CM, MJ Lallena, MA Alonso \& I Correas: An alternative domain determines nuclear localization in multifunctional protein 4.1. J Biol Chem 273, 11643-11649 (1998)

132. Luque CM \& I Correas: A constitutive region is responsible for nuclear targeting of 4.1R: modulation by alternative sequences results in differential intracellular localization. J Cell Sci 113, 2485-2495 (2000)

133. Luque CM, CM Perez-Ferreiro, A Perez-Gonzalez, L Englmeier, MD Koffa \& I Correas: An alternative domain containing a leucine-rich sequence regulates nuclear cytoplasmic localization of protein 4.1R. J Biol Chem 278, 2686-2691 (2003)

134. Luque CM, MJ Lallena, CM Perez-Ferreiro, Y de Isidro, G De Carcer, MA Alonso \& I Correas: The N-terminal 209-aa domain of high molecular-weight 4.1R isoforms abrogates 4.1R targeting to the nucleus. Proc Natl Acad Sci US A. 96, 1492514930 (1999)

135. Mattagajasingh SN, SC Huang, JS Hartenstein \& EJ Jr Benz: Characterization of the interaction between protein 4.1R and ZO-2. A possible link between the tight junction and the actin cytoskeleton. J Biol Chem 275, 30573-30585 (2000)

136. Leclerc E \& S Vetter: Characterization of a calcium-dependent calmodulin-binding domain in the 135-kD human protein 4.1 isoform. Eur J Biochem 258, 567-571 (1998)

137. Manno S, Y Takakuwa \& N Mohandas: Modulation of erythrocyte membrane mechanical function by protein 4.1 phosphorylation. J Biol Chem 280, 7581-7587 (2005)

138. van Adelsberg J: Protein targeting: the molecular basis of vectorial transport in the kidney. Semin Nephrol 18, $152-166$. (1998)

139. Nelson WJ \& PJ Veshnock: Ankyrin binding to $(\mathrm{Na}++\mathrm{K}+)$ ATPase and implications for the organization of membrane domains in polarized cells. Nature 328, 533-536 (1987)

140. Nelson WJ \& RW Hammerton: A membrane-cytoskeletal complex containing $\mathrm{Na}+, \mathrm{K}+$-ATPase, ankyrin, and fodrin in Madin-Darby canine kidney (MDCK) cells: implications for the biogenesis of epithelial cell polarity. J Cell Biol 108, 893-902 (1989)

141. Nelson WJ: Topogenesis of plasma membrane domains in polarized epithelial cells. Curr Opin Cell Biol 1, 660-668 (1989)

142. Smith PR, G Saccomani, EH Joe, KJ Angelides \& DJ Benos: Amiloride-sensitive sodium channel is linked to the cytoskeleton in renal epithelial cells. Proc Natl Acad Sci U S A. 88, 6971-6975 (1991) 
143. Kraemer DM, B Strizek, HE Meyer, K Marcus \& D Drenckhahn: Kidney $\mathrm{Na}+, \mathrm{K}(+)$-ATPase is associated with moesin. Eur J Cell Biol 82, 87-92 (2003)

144. Chow CW: Regulation and intracellular localization of the epithelial isoforms of the Na+/H+ exchangers NHE2 and NHE3. Clin Invest Med. 22, 195-206 (1999)

145. Glynne PA \& TJ Evans: Role of the PDZ scaffolding protein in tubule cells in maintenance of polarised function. Exp Nephrol 10, 307-312 (2002)

146. Marrs JA, EW Napolitano, C Murphy-Erdosh, RW Mays, LF Reichardt \& WJ Nelson: Distinguishing roles of the membrane-cytoskeleton and cadherin mediated cell-cell adhesion in generating different $\mathrm{Na}+, \mathrm{K}(+)$-ATPase distributions in polarized epithelia. J Cell Biol 123, 149-164 (1993)

147. Piepenhagen PA, LL Peters, SE Lux \& WJ Nelson: Differential expression of $\mathrm{Na}(+)-\mathrm{K}(+)$-ATPase, ankyrin, fodrin, and Ecadherin along the kidney nephron. Am J Physiol 269, C1417-1432. (1995)

148. McNeill H, M Ozawa, R Kemler \& WJ Nelson: Novel function of the cell adhesion molecule uvomorulin as an inducer of cell surface polarity. Cell 62, 309-316 (1990)

149. Nelson WJ, RW Hammerton, AZ Wang \& EM Shore: Involvement of the membrane-cytoskeleton in development of epithelial cell polarity. Semin Cell Biol 1, 359-371 (1990)

150. Salas PJ, MI Ponce, M Brignoni \& ML Rodriguez: Attachment of Madin-Darby canine kidney cells to extracellular matrix: role of a laminin binding protein related to the $37 / 67 \mathrm{kDa}$ laminin receptor in the development of plasma membrane polarization. Biol Cell 75, 197-210 (1992)

151. Zinkl GM, A Zuk, P van der Bijl, G van Meer \& KS Matlin: An antiglycolipid antibody inhibits Madin-Darby canine kidney cell adhesion to laminin and interferes with basolateral polarization and tight junction formation. J Cell Biol 133, 695-708 (1996)

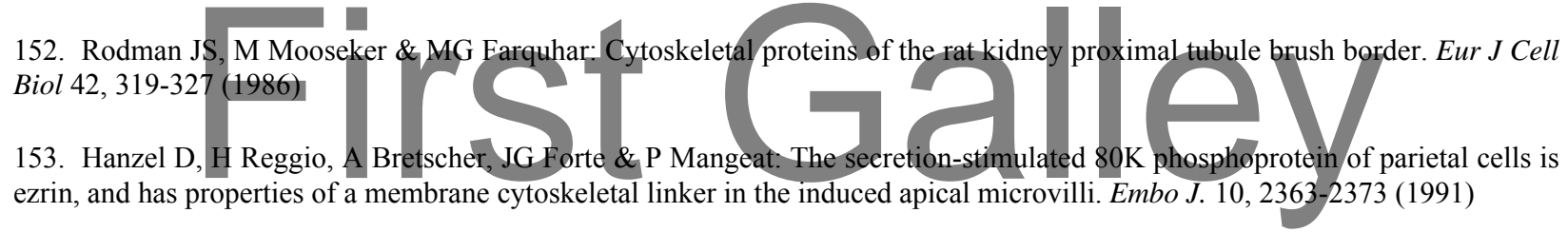

154. Morales FC, Y Takahashi, EL Kreimann \& MM Georgescu: Ezrin-radixin-moesin (ERM)-binding phosphoprotein 50 organizes ERM proteins at the apical membrane of polarized epithelia. Proc Natl Acad Sci U S A 101, 17705-17710. (2004)

155. Huang T, Y You, MS Spoor, EJ Richer, VV Kudva, RC Paige, MP Seiler, JM Liebler, J Zabner, CG Plopper \& SL Brody: Foxj1 is required for apical localization of ezrin in airway epithelial cells. J Cell Sci 116, 4935-4945 (2003)

156. Minkoff C, S Shenolikar \& EJ Weinman: Assembly of signaling complexes by the sodium-hydrogen exchanger regulatory factor family of PDZ-containing proteins. Curr Opin Nephrol Hypertens 8, 603-608 (1999)

157. Moyer BD, J Denton, KH Karlson, D Reynolds, S Wang,, JE Mickle, M Milewski, GR Cutting, WB Guggino, M Li \& BA Stanton: A PDZ-interacting domain in CFTR is an apical membrane polarization signal. J Clin Invest 104, 1353-1361 (1999)

158. Wade JB, PA Welling, M Donowitz, S Shenolikar \& EJ Weinman: Differential renal distribution of NHERF isoforms and their colocalization with NHE3, ezrin, and ROMK. Am J Physiol Cell Physiol 280, C192-198. (2001)

159. Discher DE, R Winardi, PO Schischmanoff, M Parra, JG Conboy \& N Mohandas: Mechanochemistry of protein 4.1's spectrin-actin-binding domain: ternary complex interactions, membrane binding, network integration, structural strengthening. $J$ Cell Biol 130, 897-907 (1995)

160. Discher D, M Parra, JG Conboy \& N Mohandas: Mechanochemistry of the alternatively spliced spectrin-actin binding domain in membrane skeletal protein 4.1. J Biol Chem 268, 7186-7195 (1993) 
161. Correas I, CM Perez-Ferreiro, MJ Lallena \& CM Luque: Nuclear and Cytoplasmic Localization Signals in Protein 4.1R. Cell Mol Biol Lett 6, 195 (2001)

162. Shi ZT, V Afzal, B Coller, D Patel, JA Chasis, M Parra, G Lee, C Paszty, M Stevens, L Walensky, LL Peters, N Mohandas, E Rubin \& JG Conboy: Protein 4.1R-deficient mice are viable but have erythroid membrane skeleton abnormalities. J Clin Invest 103, 331-340 (1999)

163. De Franceschi L, A Rivera, I Bize, M Fleming, LL Peters, P Gascard, N Mohandas \& C Brugnara: Murine spherocytosis: evidence for a functional interaction between protein 4.1 and $\mathrm{Na} / \mathrm{H}$ exchange and for a "protective" role of the Gardos channel against hemolysis. Blood. 104, 167a (abstract) (2004)

164. De Franceschi L, A Rivera, MD Fleming, M Honczarenko, LL Peters, P Gascard, N Mohandas \& C Brugnara: Evidence for a protective role of the Gardos channel against hemolysis in murine spherocytosis. Blood in press (2005)

165. Orellana SA, AM Quinones \& ML Mandapat: Ezrin distribution is abnormal in principal cells from a murine model of autosomal recessive polycystic kidney disease. Pediatr Res 54, 406-412 (2003)

166. Rojek A, J Nielsen, HL Brooks, H Gong, YH Kim, TH Kwon, J Frokiaer \& S Nielsen: Altered expression of selected genes in kidney of rats with lithium-induced NDI. Am J Physiol Renal Physiol 288, F1276-1289 (2005)

167. Orlando RA, T Takeda, B Zak, S Schmieder, VM Benoit,, T McQuistan, H Furthmayr \& MG Farquhar: The glomerular epithelial cell anti-adhesin podocalyxin associates with the actin cytoskeleton through interactions with ezrin. J Am Soc Nephrol $12,1589-1598(2001)$

168. Takeda T, T McQuistan, RA Orlando \& MG Farquhar: Loss of glomerular foot processes is associated with uncoupling of podocalyxin from the actin cytoskeleton. J Clin Invest 108, 289-301 (2001)

169. Meder D, A Shevchenko, K Simons \& J Fullekrug: Gp135/podocalyxin and NHERF-2 participate in the formation of a preapical domain during polarization of MDCK cells. J Cell Biol 168, 303-313 (2005)

170. Zhao H, H Shiue, S Palkon, Y Wang, P Cullinan, JK Burkhardt, MW Musch, EB Chang \& JR Turner; Ezrin regulates NHE3 translocation and activation after Na+-glucose cotransport. Proc Nat Acad Sci U S A. 101,9485-9490 (2004)

171. Hernando N, N Deliot, SM Gisler, E Lederer, EJ Weinman, J Biber \& H Murer; PDZ-domain interactions and apical expression of type IIa Na/P(i) cotransporters. Proc Natl Acad Sci U S A 99, 11957-11962 (2002)

172. Weinman EJ, D Steplock, M Donowitz \& S Shenolikar: NHERF associations with sodium-hydrogen exchanger isoform 3 (NHE3) and ezrin are essential for cAMP-mediated phosphorylation and inhibition of NHE3. Biochemistry 39, 6123-6129 (2000)

173. Weinman EJ, D Steplock, JB Wade \& S Shenolikar: Ezrin binding domain-deficient NHERF attenuates cAMP-mediated inhibition of $\mathrm{Na}(+) / \mathrm{H}(+)$ exchange in OK cells. Am J Physiol Renal Physiol. 281, F374-380 (2001)

174. Weinman EJ, D Steplock \& S Shenolikar: NHERF-1 uniquely transduces the cAMP signals that inhibit sodium-hydrogen exchange in mouse renal apical membranes. FEBS Lett. 536, 141-144 (2003)

175. Watts BA 3rd \& DW Good:Hyposmolality stimulates apical membrane $\mathrm{Na}(+) / \mathrm{H}(+)$ exchange and $\mathrm{HCO}(3)(-)$ absorption in renal thick ascending limb. J Clin Invest 104, 1593-1602 (1999)

176. Watts BA 3rd, T George \& DW Good:Nerve growth factor inhibits HCO3- absorption in renal thick ascending limb through inhibition of basolateral membrane $\mathrm{Na}+\mathrm{H}+$ exchange. J Biol Chem 274, 7841-7847 (1999)

177. Watts BA 3rd, JF Di Mari, RJ Davis \& DW Good: Hypertonicity activates MAP kinases and inhibits HCO-3 absorption via distinct pathways in thick ascending limb. Am J Physiol 275, F478-486 (1998)

178. Watts BA 3rd, T George \& DW Good: The basolateral NHE1 Na+/H+ exchanger regulates transepithelial HCO3absorption through actin cytoskeleton remodeling in renal thick ascending limb. J Biol Chem 280, 11439-11447 (2005) 
179. Malbert-Colas L, G Nicolas, C Galand, MC Lecomte \& D Dhermy: Identification of new partners of the epithelial sodium channel alpha subunit. C R Biol 326, 615-624 (2003)

180. Rotter B, Y Kroviarski, G Nicolas, D Dhermy \& MC Lecomte: AlphaII-spectrin is an in vitro target for caspase-2, and its cleavage is regulated by calmodulin binding. Biochem J 378, 161-168 (2004)

181. Han WD, YM Mu, XC Lu, ZM Xu, XJ Li, L Yu, HJ Song, M Li, JM Lu, YL Zhao \& CY Pan: Up-regulation of LRP16 mRNA by 17beta-estradiol through activation of estrogen receptor alpha (ERalpha), but not ERbeta, and promotion of human breast cancer MCF-7 cell proliferation: a preliminary report. Endocr Relat Cancer 10, 217-224 (2003)

182. Zhao YL, WD Han, Q Li, YM Mu, XC Lu, L Yu, HJ Song, X Li, JM Lu \& CY Pan: Mechanism of transcriptional regulation of LRP16 gene expression by 17-beta estradiol in MCF-7 human breast cancer cells. J Mol Endocrinol 34, 77-89 (2005)

183. Li X, Z Xie, \& VA Bankaitis: Phosphatidylinositol/phosphatidylcholine transfer proteins in yeast. Biochim Biophys Acta. $1486,55-71(2000)$

184. Nishimura N, H Nakamura, Y Takai \& K Sano: Molecular cloning and characterization of two rab GDI species from rat brain: brain-specific and ubiquitous types. J Biol Chem 269, 14191-14198 (1994)

185. Bachner D, Z Sedlacek, B Korn, H Hameister \& A Poustka: Expression patterns of two human genes coding for different rab GDP-dissociation inhibitors (GDIs), extremely conserved proteins involved in cellular transport. Hum Mol Genet 4, 701-708 (1995)

186. Pfeffer SR: Rab GTPases: master regulators of membrane trafficking. Curr Opin Cell Biol 6, 522-526 (1994)

187. Stein MP, J Dong \& A Wandinger-Ness: Rab proteins and endocytic trafficking: potential targets for therapeutic intervention. Adv Drug Deliv Rev 55, 1421-1437 (2003)

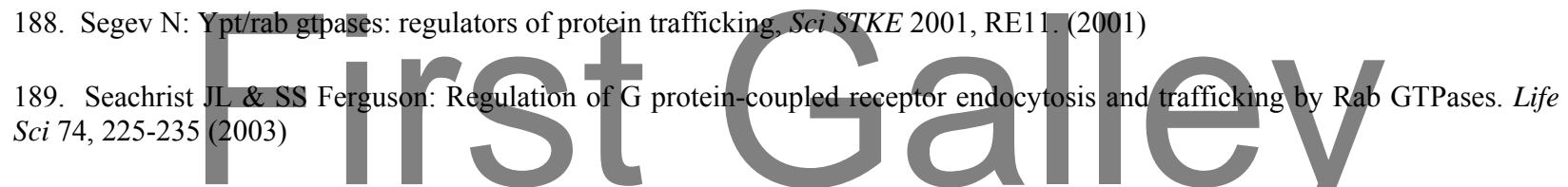

190. Gonzalez L Jr. \& RH Scheller: Regulation of membrane trafficking: structural insights from a Rab/effector complex. Cell 96, 755-758 (1999)

191. Gerges NZ, DS Backos \& JA Esteban: Local control of AMPA receptor trafficking at the postsynaptic terminal by a small GTPase of the Rab family. J Biol Chem 279, 43870-43878. (2004)

192. Greenfield JP, RS Gross, GK Gouras \& H Xu: Cellular and molecular basis of beta-amyloid precursor protein metabolism. Front Biosci 5, D72-83. (2000)

193. Brands JH, JA Maassen, FJ van Hemert, R Amons \& W Moller: The primary structure of the alpha subunit of human elongation factor 1. Structural aspects of guanine-nucleotide-binding sites. Eur J Biochem 155, 167-171. (1986)

194. Condeelis J: Elongation factor 1 alpha, translation and the cytoskeleton. Trends Biochem Sci 20, 169-170 (1995)

195. Katoh M:Identification and characterization of TMEM24 family genes in silico. Int J Oncol 25, 759-764 (2004)

196. Haass C, EH Koo, A Mellon, AY Hung \& DJ Selkoe: Targeting of cell-surface beta-amyloid precursor protein to lysosomes: alternative processing into amyloid-bearing fragments. Nature 357, 500-503 (1992)

197. Haass C, EH Koo, DB Teplow \& DJ Selkoe: Polarized secretion of beta-amyloid precursor protein and amyloid betapeptide in MDCK cells. Proc Natl Acad Sci U S A. 91, 1564-1568 (1994)

198. Haass C, EH Koo, A Capell, DB Teplow \& DJ Selkoe: Polarized sorting of beta-amyloid precursor protein and its proteolytic products in MDCK cells is regulated by two independent signals. J Cell Biol 128, 537-547 (1995) 
199. De Strooper B, K Craessaerts, I Dewachter, D Moechars, B Greenberg, F Van Leuven \& H Van den Berghe: Basolateral secretion of amyloid precursor protein in Madin-Darby canine kidney cells is disturbed by alterations of intracellular pH and by introducing a mutation associated with familial Alzheimer's disease. J Biol Chem. 270, 4058-4065 (1995)

200. Sihag RK, LW Wang, AM Cataldo, M Hamlin, CM Cohen \& RA Nixon: Evidence for the association of protein 4.1 immunoreactive forms with neurofibrillary tangles in Alzheimer's disease brains. Brain Res 656, 14-26 (1994)

201. Umahara T, T Uchihara, K Tsuchiya, A Nakamura, T Iwamoto, K Ikeda \& M Takasaki: 14-3-3 proteins and zeta isoform containing neurofibrillary tangles in patients with Alzheimer's disease. Acta Neuropathol (Berl) 108, 279-286 (2004)

202. De Matteis MA \& JS Morrow: The role of ankyrin and spectrin in membrane transport and domain formation. Curr Opin Cell Biol 10, 542-549 (1998)

203. Lippincott-Schwartz J: Cytoskeletal proteins and Golgi dynamics. Curr Opin Cell Biol 10, 52-59 (1998)

204. Lee RK, RJ Wurtman, AJ Cox \& RM Nitsch: Amyloid precursor protein processing is stimulated by metabotropic glutamate receptors. Proc Natl Acad Sci U S A 92, 8083-8087 (1995)

205. Lee RK, J Jimenez, AJ Cox \& RJ Wurtman: Metabotropic glutamate receptors regulate APP processing in hippocampal neurons and cortical astrocytes derived from fetal rats. Ann N Y Acad Sci 777, 338-343 (1996)

206. Dougherty MK \& DK Morrison: Unlocking the code of 14-3-3. J Cell Sci 117, 1875-1884 (2004)

207. Masters SC, RR Subramanian, A Truong, H Yang, K Fujii, H Zhang, \& H Fu: Survival-promoting functions of 14-3-3 proteins. Biochem Soc Trans 30, 360-365 (2002)

208. van Hemert MJ, HY Steensma \& GP van Heusden: 14-3-3 proteins: key regulators of cell division, signalling and apoptosis. Bioessays 23, 936-946 (2001)

209. Baldin V: 14-3-3 proteins and growth control. Prog Cell Cycle Res 4, 49-60 (2000)

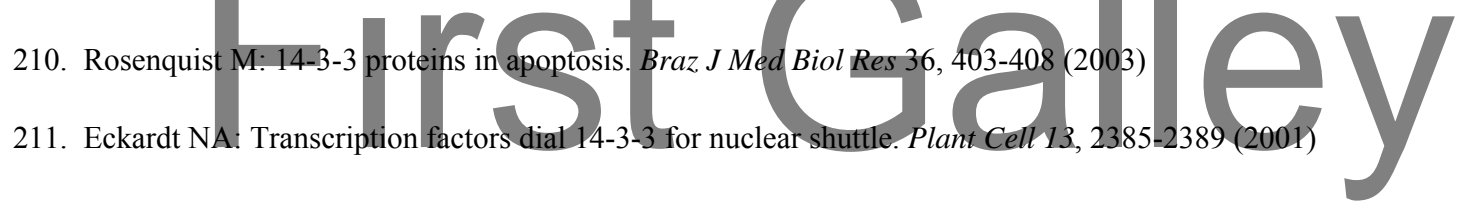

212. Muslin AJ \& H Xing: 14-3-3 proteins: regulation of subcellular localization by molecular interference. Cell Signal. 12, 703709 (2000)

213. Carreno FR, CN Goni, LM Castro \& ES Ferro: 14-3-3 epsilon modulates the stimulated secretion of endopeptidase 24.15 . $J$ Neurochem 93, 10-25 (2005)

214. Aitken A: 14-3-3 and its possible role in co-ordinating multiple signalling pathways. Trends Cell Biol 6, 341-347 (1996)

215. Burbelo PD \& A Hall: 14-3-3 proteins. Hot numbers in signal transduction. Curr Biol 5, 95-96 (1995)

216. Reuther GW \& AM Pendergast: The roles of 14-3-3 proteins in signal transduction. Vitam Horm 52, 149-175 (1996)

217. Xiao B, SJ Smerdon, DH Jones, GG Dodson, Y Soneji, A Aitken \& SJ Gamblin: Structure of a 14-3-3 protein and implications for coordination of multiple signalling pathways. Nature 376, 188-191 (1995)

218. Morrison D: 14-3-3: modulators of signaling proteins?. Science 266, 56-57 (1994)

219. Davare MA, T Saneyoshi, ES Guire, SC Nygaard \& TR Soderling: Inhibition of calcium/calmodulin-dependent protein kinase kinase by protein 14-3-3. J Biol Chem 279, 52191-52199 (2004)

220. Benton R \& D St Johnston: Drosophila PAR-1 and 14-3-3 inhibit Bazooka/PAR-3 to establish complementary cortical domains in polarized cells. Cell 115, 691-704 (2003) 
221. Brajenovic M, G Joberty, B Kuster, T Bouwmeester \& G Drewes: Comprehensive proteomic analysis of human Par protein complexes reveals an interconnected protein network. J Biol Chem 279, 12804-12811 (2004)

222. Hurd TW, S Fan, CJ Liu, HK Kweon, K Hakansson \& B Margolis: Phosphorylation-dependent binding of 14-3-3 to the polarity protein Par3 regulates cell polarity in mammalian epithelia. Curr Biol 13, 2082-2090 (2003)

223. Izaki T, S Kamakura, M Kohjima \& H Sumimoto: Phosphorylation-dependent binding of 14-3-3 to Par3beta, a human Par3-related cell polarity protein. Biochem Biophys Res Commun 329, 211-218 (2005)

224. Gohla A \& GM Bokoch: 14-3-3 regulates actin dynamics by stabilizing phosphorylated cofilin. Curr Biol 12, 1704-1710 (2002)

225. Hashiguchi M, K Sobue \& HK Paudel: 14-3-3zeta is an effector of tau protein phosphorylation. J Biol Chem 275, 25247$25254(2000)$

226. Liao J \& MB Omary: 14-3-3 proteins associate with phosphorylated simple epithelial keratins during cell cycle progression and act as a solubility cofactor. $J$ Cell Biol 133, 345-357 (1996)

227. Bunney TD, PW van den Wijngaard \& AH de Boer: 14-3-3 protein regulation of proton pumps and ion channels. Plant Mol Biol 50, 1041-1051 (2002)

228. Efendiev R, Z Chen, RT Krmar, S Uhles, AI Katz, CH Pedemonte \& AM Bertorello: The 14-3-3 protein translates the $\mathrm{NA}+, \mathrm{K}+$-ATPase $\{$ alpha\} 1-subunit phosphorylation signal into binding and activation of phosphoinositide 3-kinase during endocytosis. J Biol Chem 280, 16272-16277 (2005)

229. Eder PS, CJ Soong, \& M Tao: Phosphorylation reduces the affinity of protein 4.1 for spectrin. Biochemistry 25, 1764-1770 (1986)

230. Ling E, YN Danilov \& CM Cohen: Modulation of red cell band 4.1 function by cAMP-dependent kinase and protein kinase C phosphorylation. J Biol Chem 263, 2209-2216 (1988)

231. Pinder JC, B Gardner \& WB Gratzer: Interaction of protein 4.1 with the red cell membrane: effects of phosphorylation by protein kinase C. Biochem Biophys Res Commun 210, 478-482 (1995)

232. Subrahmanyam G, PJ Bertics \& RA Anderson: Phosphorylation of protein 4.1 on tyrosine- 418 modulates its function in vitro. Proc Natl Acad Sci U S A. 88, 5222-5226 (1991)

233. Jin J, FD Smith, C Stark, CD Wells, JP Fawcett, S Kulkarni, P Metalnikov, P O'Donnell, P Taylor, L Taylor, A Zougman, JR Woodgett, LK Langeberg, JD Scott \& T Pawson: Proteomic, functional, and domain-based analysis of in vivo 14-3-3 binding proteins involved in cytoskeletal regulation and cellular organization. Curr Biol 14, 1436-1450 (2004)

234. Pietromonaco SF, GA Seluja, A Aitken \& L Elias: Association of 14-3-3 proteins with centrosomes. Blood Cells Mol Dis 22, 225-237 (1996)

235. Burg MB: Molecular basis of osmotic regulation. Am J Physiol 268, F983-996 (1995)

236. Waldegger S \& F Lang: Cell volume-regulated gene transcription. Kidney Blood Press Res 21, 241-244 (1998)

237. Warntges S, HJ Grone, G Capasso \& F Lang: Cell volume regulatory mechanisms in progression of renal disease. $J$ Nephrol 14, 319-326 (2001)

238. Burckhardt G, F Di Sole \& C Helmle-Kolb: The Na+/H+ exchanger gene family. J Nephrol 15 Suppl 5, S3-21 (2002)

239. Demaurex N \& S Grinstein: Na+/H+ antiport: modulation by ATP and role in cell volume regulation. J Exp Biol 196, 389404 (1994)

240. Grinstein S, M Woodside, C Sardet, J Pouyssegur \& D Rotin: Activation of the Na+/H+ antiporter during cell volume regulation. Evidence for a phosphorylation-independent mechanism. J Biol Chem 267, 23823-23828 (1992) 
241. Bustamante M, F Roger, ML Bochaton-Piallat, G Gabbiani, PY Martin \& E Feraille: Regulatory volume increase is associated with p38 kinase-dependent actin cytoskeleton remodeling in rat kidney MTAL. Am J Physiol Renal Physiol 285, F336-347 (2003)

242. Pedersen SF, EK Hoffmann \& JW Mills: The cytoskeleton and cell volume regulation. Comp Biochem Physiol A Mol Integr Physiol 130, 385-399 (2001)

243. Szaszi K, S Grinstein, J Orlowski \& A Kapus: Regulation of the epithelial $\mathrm{Na}(+) / \mathrm{H}(+)$ exchanger isoform by the cytoskeleton. Cell Physiol Biochem 10, 265-272 (2000)

244. Furst J, M Gschwentner, M Ritter, G Botta, M Jakab, M Mayer, L Garavaglia, C Bazzini, S Rodighiero, G Meyer, S Eichmuller, E Woll \& M Paulmichl: Molecular and functional aspects of anionic channels activated during regulatory volume decrease in mammalian cells. Pflugers Arch. 444, 1-25 (2002)

245. Sardini A, JS Amey, KH Weylandt, M Nobles, MA Valverde \& CF Higgins: Cell volume regulation and swelling-activated chloride channels. Biochim Biophys Acta 1618, 153-162 (2003)

246. Pu WT, K Wickman \& DE Clapham: ICln is essential for cellular and early embryonic viability. J Biol Chem 275, 12363$12366(2000)$

247. Gschwentner M, A Susanna, A Schmarda, A Laich, UO Nagl, H Ellemunter, P Deetjen, J Frick \& M Paulmichl: ICln: a chloride channel paramount for cell volume regulation. J Allergy Clin Immunol 98, S98-101; discussion S105-106 (1996)

248. Furst J, C Bazzini, M Jakab, G Meyer, M Konig, M Gschwentner, M Ritter, A Schmarda, G Botta, R Benz, P Deetjen \& M Paulmichl: Functional reconstitution of ICln in lipid bilayers. Pflugers Arch. 440, 100-115 (2000)

249. Chen L, L Wang, \& TJ Jacob: Association of intrinsic pICln with volume-activated Cl- current and volume regulation in a native epithelial cell. Am J Physiol 276, C182-192 (1999)

250. Laich A, M Gschwentner, W Krick, UO Nagl, J Furst, S Hofer, A Susanna, A Schmarda, P. Deetjen, G Burckhardt \& M Paulmichl: ICln, a chloride channel cloned from kidney cells, is activated during regulatory volume decrease. Kidney Int 51, 477478 (1997)

251. Schwartz RS, AC Rybicki \& RLNagel: Molecular cloning and expression of a chloride channel-associated protein pICln in human young red blood cells: association with actin. Biochem J 327, 609-616 (1997)

252. Larkin D, D Murphy, DF Reilly, M Cahill, E Sattler, P Harriott, DJ Cahill \& N Moran: ICln, a novel integrin alphaIIbbeta3associated protein, functionally regulates platelet activation. J Biol Chem 279, 27286-27293 (2004)

253. Ritter M, A Ravasio, M Jakab, S Chwatal, J Furst, A Laich, M Gschwentner, S Signorelli, C Burtscher, S Eichmuller \& M Paulmichl: Cell swelling stimulates cytosol to membrane transposition of Icln. J Biol Chem 278, 50163-50174 (2003)

254. Emma F, S Breton, R Morrison, S Wright \& K Strange: Effect of cell swelling on membrane and cytoplasmic distribution of pICln. Am J Physiol 274, C1545-1551 (1998)

255. Emma F, R Sanchez-Olea \& K Strange: Characterization of $\mathrm{pI}(\mathrm{Cln})$ binding proteins: identification of p17 and assessment of the role of acidic domains in mediating protein-protein interactions. Biochim Biophys Acta 1404, 321-328. (1998)

256. Krapivinsky G, W Pu, K Wickman, L Krapivinsky \& DE Clapham: pICln binds to a mammalian homolog of a yeast protein involved in regulation of cell morphology. J Biol Chem 273, 10811-10814 (1998)

257. Bao S, Y Qyang, P Yang, H Kim, H Du, G Bartholomeusz, J Henkel, R Pimental, F Verde \& S Marcus: The highly conserved protein methyltransferase, $\mathrm{Skb1}$, is a mediator of hyperosmotic stress response in the fission yeast Schizosaccharomyces pombe. J Biol Chem 276, 14549-14552 (2001)

258. Abo A, J Qu, MS Cammarano, C Dan, A Fritsch, V Baud, B Belisle \& A Minden: PAK4, a novel effector for Cdc42Hs, is implicated in the reorganization of the actin cytoskeleton and in the formation of filopodia. Embo J. 17, 6527-6540 (1998) 
259. Liang M, AW Jr Cowley, MJ Hessner, J Lazar, DP Basile \& JL Pietrusz: Transcriptome analysis and kidney research: Toward systems biology. Kidney Int 67, 2114-2122 (2005)

260. Puttini S, A Ouvrard-Pascaud, G Palais, AT Beggah, P Gascard, M Cohen-Tannoudji, C Babinet, M Blot-Chabaud \& F Jaisser: Development of a targeted transgenesis strategy in highly differentiated cells: a powerful tool for functional genomic analysis. J Biotechnol 116, 145-151 (2005)

261. Ye K, DA Compton, MM Lai, LD Walensky \& SH Snyder: Protein 4.1N binding to nuclear mitotic apparatus protein in PC12 cells mediates the antiproliferative actions of nerve growth factor. J Neurosci 19, 10747-10756 (1999)

262. Ye K, KJ Hurt, FY Wu, M Fang, HR Luo, JJ Hong, S Blackshaw, CD Ferris \& SH Snyder: Pike. A nuclear gtpase that enhances PI3kinase activity and is regulated by protein 4.1N. Cell 103, 919-930 (2000)

263. Tran YK, O Bogler, KM Gorse, I Wieland, MR Green \& IF Newsham: A novel member of the NF2/ERM/4.1 superfamily with growth suppressing properties in lung cancer. Cancer Res 59, 35-43 (1999)

264. Gutmann DH, AC Hirbe, ZY Huang \& CA Haipek: The protein 4.1 tumor suppressor, DAL-1, impairs cell motility, but regulates proliferation in a cell-type-specific fashion. Neurobiol Dis 8, 266-278 (2001)

265. Hui AB, KW Lo, J Kwong, EC Lam, SY Chan, LS Chow, AS Chan, PM Teo \& DP Huang: Epigenetic inactivation of TSLC1 gene in nasopharyngeal carcinoma. Mol Carcinog 38, 170-178 (2003)

266. Tamura G: Promoter methylation status of tumor suppressor and tumor-related genes in neoplastic and non-neoplastic gastric epithelia. Histol Histopathol 19, 221-228 (2004)

267. Coupaye-Gerard B, C Bookstein, P Duncan, XY Chen, PR Smith, M Musch, SA Ernst, EB Chang \& TR Kleyman: Biosynthesis and cell surface delivery of the NHE1 isoform of Na+/H+ exchanger in A6 cells. Am J Physiol 271, C1639-1645 (1996)

268. Tang Y, V Katuri, A Dillner, B Mishra, CX Deng, \& L Mishra: Disruption of transforming growth factor-beta signaling in ELF beta-spectrin-deficient mice. Science 299, 574-577 (2003)

269. Paradiso A, RA Cardone, A Bellizzi, A Bagorda, L Guerra, M Tommasino, V Casavola \& SJ Reshkín: The Na+-H+ exchanger-1 induces cytoskeletal changes inyolving reciprocal RhoA and Racl signaling, resulting in motility and invasion in MDA-MB-435 cells. Breast Cancer Res 6, R616-28 (2004)

270. Sun CX, VA Robb \& DH Gutmann: Protein 4.1 tumor suppressors: getting a FERM grip on growth regulation. $J$ Cell Sci $115,3991-4000(2002)$

271. Rong R, X Tang, DH Gutmann \& K Ye: (2004) Neurofibromatosis 2 (NF2) tumor suppressor merlin inhibits phosphatidylinositol 3-kinase through binding to PIKE-L. Proc Natl Acad Sci U S A 101, 18200-18205.

272. Akisawa N, I Nishimori, T Iwamura, S Onishi \& MA Hollingsworth: High levels of ezrin expressed by human pancreatic adenocarcinoma cell lines with high metastatic potential. Biochem Biophys Res Commun 258, 395-400 (1999)

273. Shen ZY, LY Xu, MH Chen, EM Li, JT Li, XY Wu \& Y Zeng: Upregulated expression of Ezrin and invasive phenotype in malignantly transformed esophageal epithelial cells. World J Gastroenterol 9, 1182-1186 (2003)

274. Fais S: A role for ezrin in a neglected metastatic tumor function. Trends Mol Med. 10, 249-250 (2004)

275. Hunter KW: Ezrin, a key component in tumor metastasis. Trends Mol Med. 10, 201-204 (2004)

276. Curto M \& AI McClatchey: Ezrin...a metastatic detERMinant?. Cancer Cell 5, 113-114 (2004)

277. Gautreau A, P Poullet, D Louvard \& M Arpin: Ezrin, a plasma membrane-microfilament linker, signals cell survival through the phosphatidylinositol 3-kinase/Akt pathway. Proc Natl Acad Sci U S A. 96, 7300-7305 (1999)

278. Pujuguet P, L Del Maestro, A Gautreau, D Louvard \& M Arpin: Ezrin regulates E-cadherin-dependent adherens junction assembly through Rac1 activation. Mol Biol Cell 14, 2181-2191 (2003) 
279. Elliott BE, H Qiao, D Louvard \& M Arpin: Co-operative effect of c-Src and ezrin in deregulation of cell-cell contacts and scattering of mammary carcinoma cells. J Cell Biochem 92, 16-28 (2004)

280. Wan X, A Mendoza, C Khanna \& LJ Helman: Rapamycin inhibits ezrin-mediated metastatic behavior in a murine model of osteosarcoma. Cancer Res 65, 2406-2411 (2005)

281. Liu H, DC Radisky \& MJ Bissell: Proliferation and Polarity in Breast Cancer: Untying the Gordian Knot. Cell Cycle 4. In press (2005)

282. Cardone RA, A Bagorda, A Bellizzi, G Busco, L Guerra, A Paradiso, V Casavola, M Zaccolo \& SJ Reshkin: PKA Gating of a Pseudopodial Located RhoA/ROCK/p38/NHE1 Signal Module Regulates Invasion in Breast Cancer Cell Lines. Mol Biol Cell In press (2005)

283. Martin TA, G Harrison, RE Mansel \& WG Jiang,: The role of the CD44/ezrin complex in cancer metastasis. Crit Rev Oncol Hematol 46, 165-186 (2003)

284. Speck O, SC Hughes, NK Noren, RM Kulikauskas \& RG Fehon: Moesin functions antagonistically to the Rho pathway to maintain epithelial integrity. Nature 421, 83-87 (2003)

285. Lang F, M Ritter, N Gamper, S Huber, S Fillon, V Tanneur, A Lepple-Wienhues, I Szabo \& E Gulbins: Cell volume in the regulation of cell proliferation and apoptotic cell death. Cell Physiol Biochem 10, 417-28 (2000)

286. Stern RG, BN Milestone \& RA Gatenby: Carcinogenesis and the plasma membrane. Med Hypotheses 52, 367-372 (1999)

287. Bourguignon LY, PA Singleton, F Diedrich, R Stern \& E Gilad: CD44 interaction with Na+-H+ exchanger (NHE1) creates acidic microenvironments leading to hyaluronidase-2 and cathepsin B activation and breast tumor cell invasion. $J$ Biol Chem 279 , 26991-27007 (2004)

288. Pearson RB \& BE Kemp: Protein kinase phosphorylation site sequences and consensus specificity motifs: tabulations., Methods Enzymol. 200,62-81 . (1991)

Abbreviations: AD: Alzheimer's disease; beta-APP: beta-amyloid precursor protein; CD44: cluster of differentiation 44; CTD: C-terminal domain; DCT: distal convoluted tubule; ERM: Ezrin/Radixin/Moesin; FERM: Four.1/Ezrin/Radixin/Moesin; GTP: guanosine tri-phosphate; His: histidine; Leu: leucine; LOH: loss of heterozygosity; MBD: membrane binding domain; MDCK: Madin Darby canine kidney cells; NF2: neurofibromatosis 2; NHE1: sodium-proton exchanger isoform 1; NHE3: sodium-proton exchanger isoform 3; NHERF: sodium-proton exchanger regulatory factor; Npt2: sodium/phosphate co-transporter type II; PCT: proximal convoluted tubule; PDZ: Post Synaptic Density Protein 95kD / Drosophila Disc large / Zonula Occludens-1; PI-3: phosphatidylinositol-3 phosphate; PIKE: phosphatidylinositol-3 kinase enhancer; PKA: cyclic AMP-dependent protein kinase; PKC: protein kinase C; RVD: regulatory volume decrease; RVI: regulatory volume increase; SAB: spectrin-actin binding; TAL: thick ascending limb; TGF- beta: Transforming Growth Factor-beta; Trp: tryptophane; TSLC1: tumor suppressor in lung cancer 1 .

Key Words: Protein 4.1, Ezrin, beta-APP, 14-3-3 proteins, pICln, kidney, Epithelia, Cell, Volume, Proliferation, Review

Please asend correspondence to: Philippe Gascard, Ph.D., Department of Genome Biology, Life Sciences Division, Lawrence Berkeley National Laboratory, 1 Cyclotron Road, Mail stop 977-225A, Berkeley CA 94720, Tel: 510-486-6568, Fax: 510-4865586, E-mail: PDGascard@lbl.gov 
Figure 1. Domain organization of 4.1 proteins. Alignment of 4.1 proteins reveals the presence of three conserved domains (FERM domain, spectrin-actin binding (SAB) domain, and C-terminal domain (CTD)) highlighted in shades of grey and of three unique regions (U1, U2, U3) displayed as white boxes. Numbers in boxes refer to percent of identity of a given conserved domain of $4.1 \mathrm{G}, 4.1 \mathrm{~N}$ and $4.1 \mathrm{~B}$ to the corresponding $4.1 \mathrm{R}$ domain. The $4.1 \mathrm{R}$ map shows a unique region $\mathrm{U} 3$ that is only expressed in epithelial tissues. Note that the SAB domain is not conserved in $4.1 \mathrm{~N}$.

Figure 2. Mapping of the binding motifs for various binding partners in protein 4.1 FERM domain. We have highlighted known binding motifs for various binding partners in protein 4.1 FERM domain to illustrate the close proximity of these motifs and therefore the possibility of steric competition depending on cellular context. A Glu-Glu-Asp (EED) motif highlighted in red in exon 5-encoded peptide mediates interaction with anion exchanger AE1 (95). A 47 mer peptide encoded by exon 8, highlighted in purple, mediates 4.1 interaction with glycophorin C (24). Exon 9- and 11-encoded peptides highlighted in green mediates 4.1 interaction with calmodulin (111). Exon 10-encoded peptide highlighted in blue mediates 4.1 interaction with tubulin (116) and with PDZ domain-containing proteins p55 (111) and likely dlg (SAP 97) and CASK. A large peptide encompassing exons 9-11 (underlined in the sequence) is necessary for 4.1 interaction with pICln (46). The Tyr residue outlined in exon-11 encoded peptide in 4.1R corresponds to the location of the Phe responsible for 4.1B, 4.1N and 4.1G interaction with 14-3-3 proteins (50). The loss of this Phe residue in 4.1R explains the weak affinity of 4.1R for 14-3-3 proteins compared to the three other 4.1 proteins.

Figure 3. Conservation of the major PKC-dependent phosphorylation site in all four protein 4.1 members. Alignment of the amino acid sequences of the four mouse 4.1 proteins in the region subjected to PKC-dependent phosphorylation shows conservation of the key phosphorylatable $\mathrm{Ser}^{312}$ residue (in larger font and shown in blue) and of an upstream $\mathrm{Arg}^{309}$ residue $^{3}$ (shown in red). These two residues are components of the canonical PKC phosphorylation site K/R-X-X-S/T previously described in glycogen synthase (288).

Figure 4. Distinct distribution of protein 4.1B and ezrin or NHERF-1 in mouse kidney proximal convoluted tubules. Staining of paraformaldehyde-fixed mouse kidney sections was performed as previously described (71) using a goat polyclonal anti 4.1B antibody (66) diluted at $3 \mathrm{microg} / \mathrm{ml}$ in conjunction with either a rabbit polyclonal anti-ezrin antibody (Upstate USA. Inc., Charlottesville, VA) or a rabbit polyclonal anti-NHERF-1 antibody kindly provided by Dr. Stephen Lambert (University of Massachussetts, Worcester, MA) both diluted at $4 \mathrm{microg} / \mathrm{ml}$. Primary antibodies were detected using anti-goat IgGs coupled to fluorescein isothiocyanate and anti-rabbit IgGs coupled to Texas Red. As previously reported, protein 4.1B shows exclusive basolateral distribution in proximal convoluted tubules (71) while ezrin and NHERF-1 are both expressed at the apical pole of the tubules. The tubules lacking 4.1B expression but stained with anti ezrin and anti-NHERF-1 antibodies correspond to other regions of the nephron.

Figure 5. Mapping of the region responsible for mouse renal 4.1 protein interaction with rat pICln, Yeast strain L40 was cotransformed with cDNAs eneoding full length rat pICln and various mouse 4.1 constructs. Panel A: 1: full length kidney 4.1R, 2: 4.1R FERM domain, 3: 4.1R CTD domain, 4: full length kidney 4.1B, 5: 4.1B FERM domain, 6: 4.1G FERM domain. Panel B: 1: full length kidney 4.1N, 2: 4.1N FERM domain, 3: 4.1N FERM domain $\Delta 281-297,4: 4.1 \mathrm{~N}$ FERM domain $\Delta 270-297,5: 4.1 \mathrm{~N}$ FERM domain aa128-280, 6: 4.1N FERM domain aa162-280, 7: 4.1N FERM domain aa183-280. Protein-protein interaction was monitored using a standard X-Gal filter assay. +++: very strong interaction, ++: strong interaction, -: no interaction.

Figure 6. Reorganization of plasma membrane protein complexes upon epithelial cell proliferation. In a normal polarized epithelial cell, CD44, and potentially NHE1, are anchored in the lateral domain through their interaction with 4.1 proteins and the actin cytoskeleton. PDZ domain-containing proteins, such as dlg and/or CASK, would be also recruited in such complexes through interactions with 4.1 proteins (left panel). Ezrin interacts with apical transmembrane proteins such as NHE3 and recruits PDZ domain-containing proteins such as NHERF-1. Ezrin is therefore unable to interact with CD44 and NHE1 due to the mutually exclusive expression of those proteins in a different cell compartment, i.e apical pole vs. basolateral pole. Upon tumorigenesis, protein 4.1 is lost leading to disorganization of protein complexes present in lateral cell-cell contact regions and loss of cell polarity. In contrast, ezrin and its binding partner NHERF-1 become overexpressed and can now associate with CD44 and NHE1 since the localization of these proteins is no longer mutually exclusive within the plasma membrane (right panel). The formation of these novel interactions, in concert with alterations in cell microenvironment, would result in alterations of CD44 and NHE1 properties (as illustrated by changes in color patterns of those proteins between the left and the right panels) and in the formation of protein complexes that would promote cell proliferation and cell invasiveness. We speculate that a similar mechanism would occur in most proliferative epithelia, and in particular in kidney. 
Protein 4.1 in kidney physio-pathology

Table I. Potential binding partners for renal 4.1 proteins in kidney

\begin{tabular}{|l|l|l|l|}
\hline Baits & Preys & Number of clones & Site of interaction \\
\hline & & & \\
\hline kidney 4.1B & $14-3-3$ theta & $13 / 32$ & FERM \\
\hline & $14-3-3$ zeta & $7 / 32$ & FERM \\
\hline & $14-3-3$ beta & $7 / 32$ & FERM \\
\hline & pICln & $5 / 32$ & \\
\hline & & & CTD \\
\hline kidney 4.1R & LRP16 & $6 / 16$ & FERM \\
\hline & $14-3-3$ beta & $2 / 16$ & FERM \\
\hline & $14-3-3$ theta & $1 / 16$ & not determined \\
\hline & SEC14L1 & $1 / 16$ & not determined \\
\hline & Rab-GDIalpha & $2 / 16$ & CTD \\
\hline & beta-Amyloid Precursor Protein & $1 / 16$ & CTD \\
\hline & Elongation Initiation Factor 1alpha & $2 / 16$ & not determined \\
\hline & Tumor suppressor TMEM24 & $1 / 16$ & \\
\hline & & & CTD \\
\hline CTD 4.1R & alphaB-crystallin & $4 / 8$ & CTD \\
\hline & LRP16 & $2 / 8$ & CTD \\
\hline & Elongation Initiation Factor 1alpha & $2 / 8$ & \\
\hline kidney 4.1N & & & FERM \\
\hline & $14-3-3 b e t a$ & $12 / 17$ & FERM \\
\hline & $14-3-3$ theta & $3 / 17$ & FERM \\
\hline & $14-3-3 z e t a$ & $2 / 17$ & \\
\hline
\end{tabular}

The number of clones refers to the number of clones corresponding to the prey of interest relative to the total number of relevant clones pulled out with the bait. A total of $810^{6}, 3310^{6}$ and $2710^{6} \operatorname{Trp}(+)$ Leu $(+)$ yeast clones were obtained for kidney 4.1B, kidney 4.1R and kidney $4.1 \mathrm{~N}$ baits, respectively. Among those, 237, 578 and 415 clones were $\beta$-galactosidase $(+)$ Trp $(+)$ Leu $(+)$ His $(+)$, respectively. We have screened so far 74, 100 and 65 clones, respectively. Prior to screening of the library, we ascertained that none of the baits was able by itself to confer upon yeast beta-galactosidase activity and growth in absence of

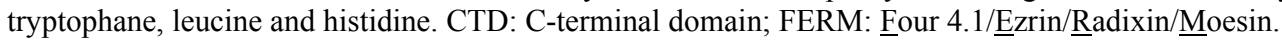




\section{FERM SAB CTD}

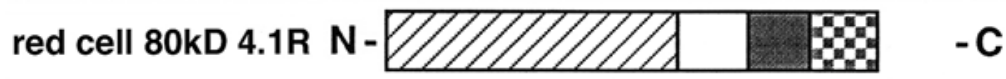

\begin{tabular}{|c|c|c|}
\hline & 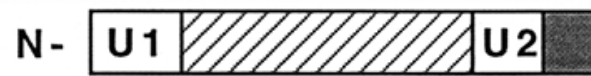 & U3 29 \\
\hline & 727111 & \\
\hline & WDIZ74" & \\
\hline & N- & 17 \\
\hline
\end{tabular}

Figure 1 (Calinisan et al.) 
Mouse 4.1R FERM domain

MHCKVSLLDDTVYECVVEKHAKGQDLLKRVCEHLNLL EEDYFGLAIWDNATSKTWLDSAKEIKKQVRGVPWNFTF NVKFYPPDPAQLTEDITRYYLCLQLRQDIVAGRLPCSFAT LALLGSYTIQSELGDYDPELHGVDYVSDFKLAPNQTKEL EEKVMELHKSYRSMTPAQADLEFLENAKKLSMYGVDL HKAKDLEGVDIILGVCSSGLLVYKDKLRINRFPWPKVLK ISYKRSSFFIKIRPGEQEQYESTIGFKLPSYRAAKKLWKV CVEHHTFFRLTSTDTIPKSKFLALGSKF

Figure 2 (Calinisan et al.) 


\section{Human 4.1R AQTRAASALID \\ Mouse 4.1B AQTRRASALID \\ Mouse 4.1R AQTRQASALID \\ Mouse 4.1G AQTREASTLID \\ Mouse 4.1N AQTRQASALID}

Figure 3 (Calinisan et al.) 

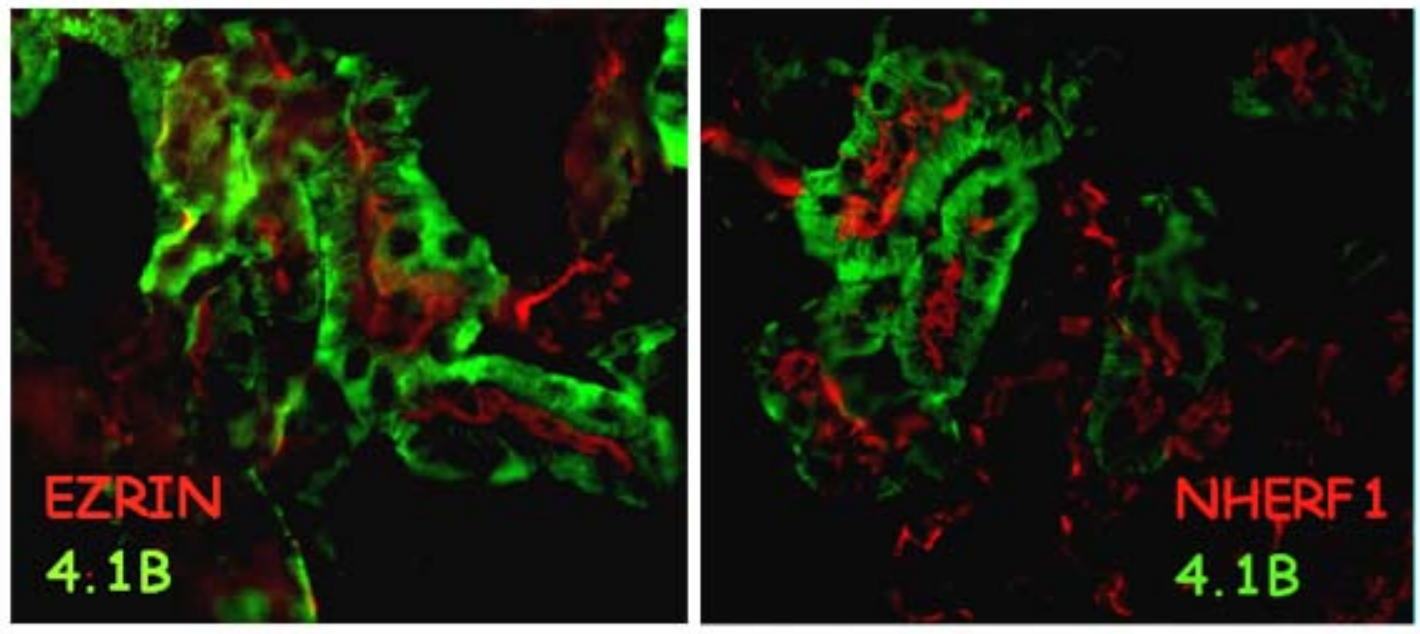

Figure 4 (Calinisan et al.) 


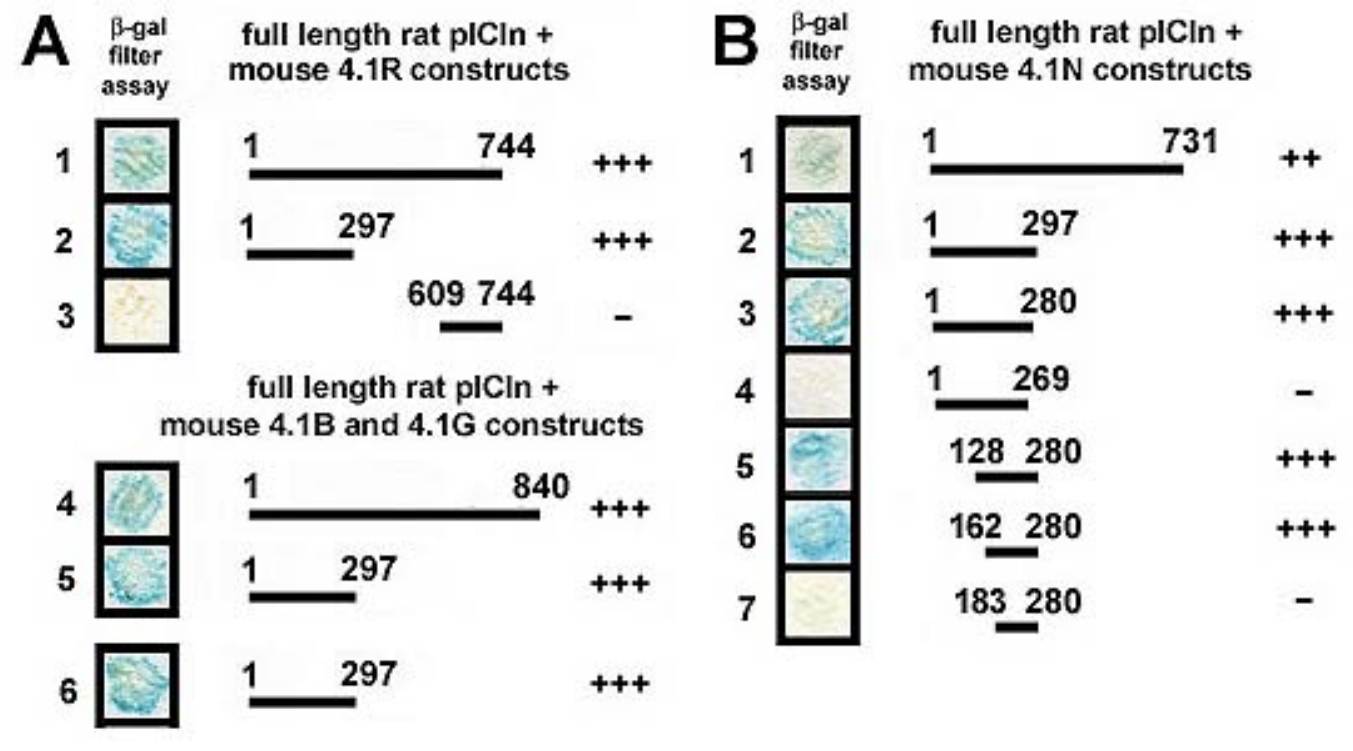

Figure 5 (Calinisan et al.) 


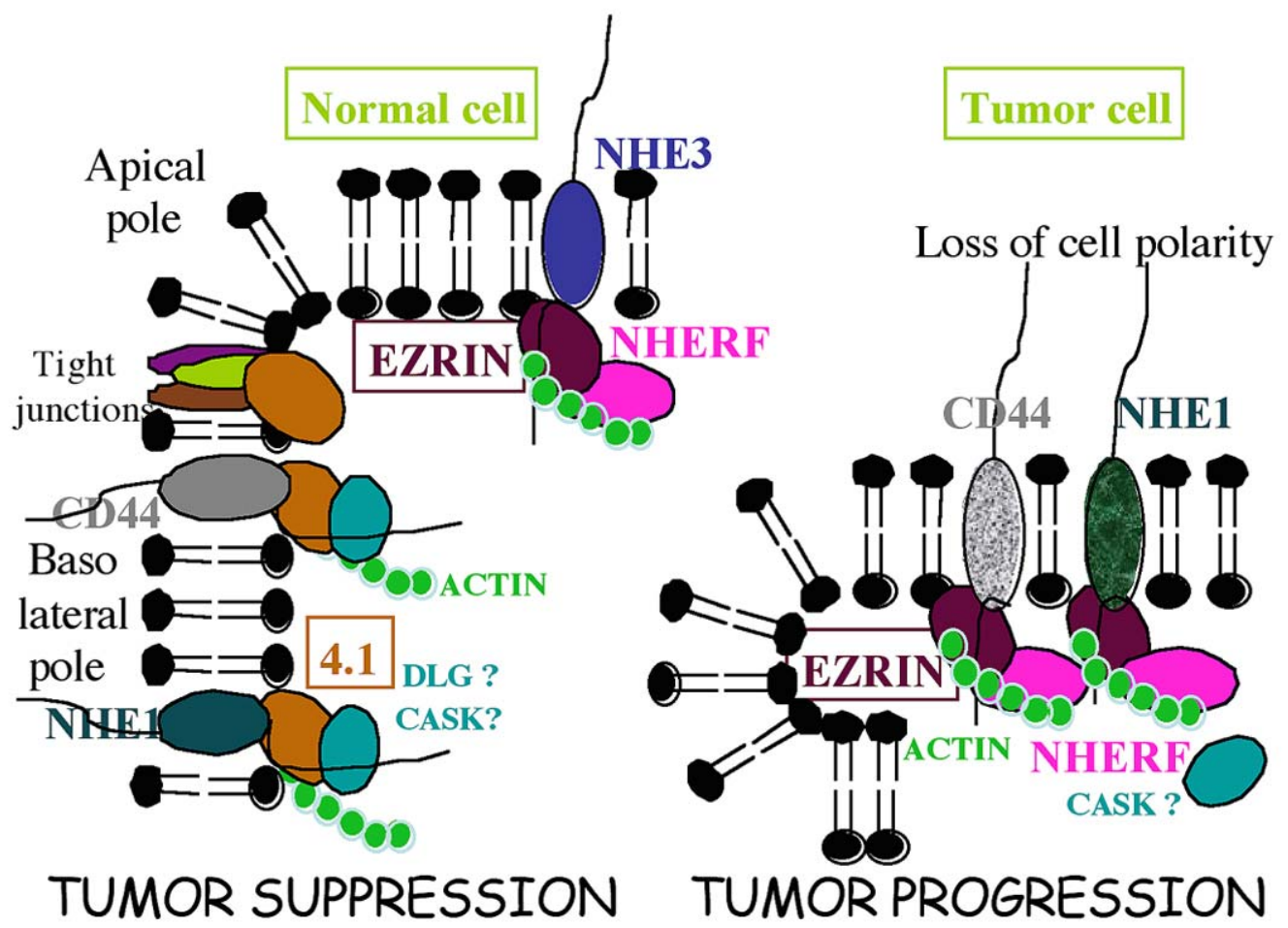

Figure 6 (Calinisan et al.) 